\title{
COMMENTS
}

\section{POLITICS AND PURPOSE: HIDE AND SEEK IN THE GERRYMANDERING THICKET AFTER DAVIS V. BANDEMER}

\author{
JON M. ANDERSON†
}

One hundred seventy-five years ago, the Boston Gazette coined the term "gerrymander" to describe a Massachusetts state senatorial redistricting ${ }^{1}$ scheme that included a salamander-shaped district drawn to benefit Governor Elbridge Gerry's political party. ${ }^{2}$ The United States Supreme Court has since addressed the constitutionality of redistricting plans based on racial discrimination ${ }^{3}$ and equal population. ${ }^{4}$ But not until 1986, in Davis v. Bandemer, ${ }^{5}$ did the Court hold that political

† A.B. 1983, Brown University; J.D. Candidate 1988, University of Pennsylvania.

${ }_{1}$ 'Technically, the words 'apportionment' and 'reapportionment' apply to the 'allocation of a finite number of representatives among a fixed number of pre-established areas,' while 'districting' and 'redistricting' refer to the drawing of district lines." Davis v. Bandemer, 106 S. Ct. 2797, 2825 n.1 (1986) (Powell, J., concurring and dissenting) (quoting Backstrom, Robins \& Eller, Issues in Gerrymandering: An Exploratory Measure of Partisan Gerrymandering Applied to Minnesota, 62 MinN. L. REv. 1121, 1121 n.1 (1978)); see also Dixon, The Warren Court Crusade for the Holy Grail of "One Man-One Vote", 1969 SuP. CT. REv. 219, 219 n.4 (noting that state legislators redistrict, not reapportion, state and federal legislative districts); Comment, Baker v. Carr and Legislative Apportionments: A Problem of Standards, 72 YALE L.J. 968, 972 n.24 (1963) (same).

2 See E. Griffith, The Rise and Development of the Gerrymander 1619 (reprint ed. 1974) (asserting that "quite likely" Gerry did not offer the egregious 1812 plan to the state legislature but was blamed when he signed it); see also $2 \mathrm{~J}$. Austin, The Life of Elbridge GerRy 347-48 (DaCapo Press ed. 1970) (1st ed. 1829) (defending Gerry for signing the redistricting act because he could find no constitutional grounds for vetoing it); G. Billias, ElbRIDGe GerRy: Founding FATHER AND RePUBlican STATESMaN 316-17 (1976) (noting that the purpose of the plan was to preserve new gains for Gerry's political party).

3 See, e.g., White v. Regester, 412 U.S. 755, 765-67 (1973) (holding that racial discrimination is inconsistent with redistricting).

4 See, e.g., Baker v. Carr, 369 U.S. 186, 209 (1962) (holding that legislative redistricting is not a nonjusticiable "political question").

B 106 S. Ct. 2797 (1986). See generally Alfange, Gerrymandering and the Constitution: Into the Thorns of the Thicket at Last, 1986 SuP. CT. REV. 175 (regarding Davis as a potentially major decision if it establishes the proposition that representational equality means more than equipopulous districts); Hess, Beyond Justiciability: 
gerrymandering-described by Justice Fortas in an earlier case as "the deliberate and arbitrary distortion of district boundaries . . . for partisan . . . political purposes" - was a justiciable question."

Not surprisingly, political response to Davis was swift. ${ }^{8}$ While the

Political Gerrymandering after Davis v. Bandemer, 9 CAMPBELl L. REv. 207 (1987) (advocating a "totality of the circumstances" for reviewing partisan gerrymandering); The Supreme Court, 1985 Term-Leading Cases, 100 HARv. L. REv. 100, 153-63 (1986) [hereinafter Leading Cases] (reviewing the Davis decision); Comment, The Court Confronts the Gerrymander, 15 FLA. ST. U.L. REv. 351 (1987) (arguing that curts should judge apportionment plans under a rational relationship test; Note, Political Gerrymandering: Judicial Scrutiny Under the Equal Protection Clause, Davis v. Bandemer, 10 Hamline L. Rev. 313 (1987) (analyzing Davis in light of past precedent); Note, Political Gerrymandering: Entangled in the Political Thicket, 16 STETson L. REv. 777 (1987) (analyzing Davis with particular attention to parallels to racial gerrymandering); D. Lowenstein, Bandemer's Gap: Gerrymandering and Equal Protection (paper presented to the American Political Science Association, Sept. 4, 1987) (arguing that Davis is a "suspect classification" as opposed to a "fundamental right" case).

6 Kirkpatrick v. Preisler, 394 U.S. 526, 538 (1969) (Fortas, J., concurring), quoted in Davis, 106 S. Ct. at 2827 (Powell, J., concurring and dissenting). As defined in this Comment, gerrymandering is intent-driven; it "results from a deliberate effort by the districting party to give itself an advantage in future elections." $P$. MusGrove, The General Theory of Gerrymandering 6 (1977). This intent-driven definition is distinguishable from a results-driven meaning, by which the existence of gerrymandering is determined by observing the " relations of votes cast to seats won in a state by the party responsible for drawing the district lines.' "Id. (quoting Sickels, Dragons, Bacon Strips and Dumbbells-Who's Afraid of Reapportionment?, 75 YALE L.J. 1300,1300 (1966)). Under the results-driven definition, all districting becomes gerrymandering since the drawing of any particular boundary line has some political effect. See id.; cf. Davis, 106 S. Ct. at 2802 (describing gerrymandering in Indiana in 1981 as "'stacking' Democrats into districts with large Democratic majorities and 'splitting' them in other districts so as to give Republicans safe but not excessive majorities in those districts"); 2 J. AustiN, supra note 2, at 345-46 (describing the same process in Massachusetts in 1812).

7 See Davis, 106 S. Ct. at 2800 (holding that gerrymandering was a justiciable question but sustaining plan involving redistricting of the Indiana state legislature); $c f$. Gaffney v. Cummings, 412 U.S. 735, 754 (1973) (sustaining a bipartisan gerrymander drawn to protect incumbents of both political parties).

As the Court has stated, justiciability may be determined by inquiring "whether the duty asserted can be judicially identified and its breach judicially determined, and whether protection for the right can be judicially molded." Baker, 369 U.S. at 198.

' See, e.g., Gurwitt, Parties Dispute Justices' Intent: Redistricting Waters Muddied by Court's Decision on Indiana, 44 CoNG. Q. WeEkLy ReP. 1641, 1641-42 (1986) (reporting interviews with attorneys for the Republican and Democratic parties); Court Disallows Gerrymandering, L.A. Times, July 1, 1986, at 12, col. 1 (quoting Republican National Committee Chairman Frank Fahrenkopf and Democratic counterpart Paul Kirk); G.O.P. Plans to Cite Ruling in California, N.Y. Times, July 1, 1986, at A17, col. 2 [hereinafter G.O.P. Plans] (quoting Fahrenkopf and Kirk). But see Lowenstein, supra note 5, at 1 (calling public reaction to Davis "a bust" in comparison to the redistricting decisions of the 1960's).

Davis also may have ramifications that implicate groups other than the two major political parties. For example, a homeowners' group tried to intervene last fall in a federal suit over the districting of the Los Angeles City Council. See United States v. City of Los Angeles, No. CV 85-7739 JMI (JRx), slip op. at 2 (C.D. Cal. Sept. 10, 
plaintiffs in Davis were Indiana Democrats, ${ }^{\circ}$ Republicans nationally hailed the justiciability of gerrymandering: they believed that Democrats, who control most state legislatures, ${ }^{10}$ have drawn state and congressional district lines to Democratic advantage. ${ }^{11}$ National Democrats, however, have minimized the impact of the decision, taking the view that the high equal protection threshold in Davis would prevent drastic restructuring. ${ }^{12}$

1986) (refusing to allow homeowners to intervene in redistricting suit). While intervention was denied, one commentator has suggested that the proposed extension to homeowners was not so farfetched after Davis. See Republicans Test High Court Ruling on House Districts, L.A. Daily J., Dec. 5, 1986, at 1, col. 2, 18, col. 4 [hereinafter Republicans Test] (statement by Professor Lowenstein); see also Cousins v. City Council, 466 F.2d 830, 850, 852-53 (7th Cir. 1972) [hereinafter Cousins I] (Stevens, J., dissenting) (recognizing as a principle that any sort of gerrymandering, be it racial, religious, ethnic, or political, is indefensible), cert. denied, 409 U.S. 893 (1972); Gomillion v. Lightfoot, 270 F.2d 594, 612 (5th Cir. 1959) (Wisdom, J., concurring) ("I can see no difference between partially disfranchising [sic] negroes and partially disfranchising [sic] Republicans, Democrats, Italians, Poles, Mexican-Americans, Catholics, bluestocking voters, industrial workers, urban citizens, or other groups . . . ."), rev'd on other grounds, 364 U.S. 339 (1960); Dyer v. Kazuhisa Abe, 138 F. Supp. 220, 236 (D. Haw. 1956) ("Any distinction between racial and geographic discrimination is artificial and unrealistic."); Karst, Paths to Belonging: The Constitution and Cultural Identity, 64 N.C.L. REv. 303, 348 (1986) (calling for judicial scrutiny of ethnic gerrymandering); Comment, supra note 1, at 972 (condemning discrimination, whether based on race, religion, or geography).

- See Davis, 106 S. Ct. at 2801; see also 2 Parties Crossing Lines in Gerrymandering Suits: Partisan Cartography Creates Odd Alliances, Wash. Post, Oct. 5, 1985, at A4, col. 4 (commenting on the irony of the Republican National Committee aligning with the plaintiff Indiana Democrats and the Democratic National Committee aligning with the defendant Indiana Republicans); Scorecards Might Be Needed for Gerrymandering Case, N.Y. Times, Sept. 13, 1985, at A20, col. 4 (noting that the NAACP, the ACLU, and Common Cause were aligned with the Democratic plaintiffs but that the Mexican-American Legal Defense Fund and the California Democratic congressional delegation were aligned with the Republican defendants).

${ }_{10}$ GOP Gains in State Elections, State Gov'T News, Dec. 1986, at 28, 28 (noting that Democrats control both chambers in 27 state legislatures whereas Republicans control both chambers in only 9 states). In addition, despite recent losses, the Democratic party holds a 26 to 24 majority of governorships. See G.O.P. Hails Governorships 'Where There Never Have Been Republicans', N.Y. Times, Nov. 6, 1986, at A31, col. 1 .

The Constitution requires the decennial reapportionment of seats in Congress among the states. See U.S. ConsT. art. I, $\S 2$, cl. 3. Congress, however, defers to the states to do the actual redistricting within each state. See 2 U.S.C. $\S 2 \mathrm{c}$ (1982). See generally Backstrom, Robins \& Eller, supra note 1, at 1121 n.2 (explaining the constitutional role of Congress in reapportionment and redistricting); Note, Constitutional Implications of a Population Undercount: Making Sense of the Census Clause, 69 GEO. L.J. 1427, 1433 n.41 (1981) (arguing that states are required to use federal census figures but noting contrary case law); infra note 320 (examining the historical role of Congress).

11 See supra note 8.

12 See Court Disallows Gerrymandering, supra note 8, at 12, col. 1 ("Democratic National Committee Chairman ... Kirk . . . said the decision was not 'a quick fix' for Republicans who have failed 'to win control of more legislatures.' The decision sets 
Despite their different interpretations of Davis, both Republicans and Democrats recognize the decision's impact on future redistricting litigation. ${ }^{13}$ But the inability of the parties to agree on the decision's ramifications foreshadows a litigious future. In the short run, Davis could play a major role in the Badham litigation, ${ }^{14}$ the last major redistricting case of the 1980-90 decennial cycle still unresolved..$^{15}$ Badham is a challenge to the 1983 California congressional redistricting plan, a plan under which the Democrats registered a net gain of five seats. ${ }^{16}$ The stakes loom even higher in the long run. In 1990, all fifty states will redistrict again and adopt state legislative and congressional districting plans that will remain in effect until $2000 .{ }^{17}$

'some very tough standards of proof that any discrimination has occurred against a political group,' he noted."); cf. G.O.P. Optimistic on Apportioning, N.Y. Times, Feb. 18, 1964, at 31, col. 8 (noting similarly confident Democratic reaction to Reynolds v. Sims, 377 U.S. 533 (1964) (applying the standard of one person-one vote to state legislature redistricting)).

1s See supra note 8; see also Brace \& Katosh, Redistricting Lawsuits Will be a New Growth Industry, Wall St. J., Aug. 29, 1986, at 16, col. 2 (editorial) ("If you think political campaigns are already too long and costly, just wait until you see the 'campaigns' to change the redistricting lines drawn after the next census . . . ."); $c f$. Davis, $106 \mathrm{~S}$. Ct. at 2818 (O'Connor, J., concurring in the judgment) ("Federal courts will have no alternative but to attempt to recreate the complex process of legislative apportionment ....".).

14 Badham v. United States Dist. Court, 721 F.2d 1170, 1172 (9th Gir. 1983) (abstaining from ruling on the constitutionality of an alleged congressional gerrymander in California until state law issues resolved by state court). See generally Hess, supra note 5, at 211-13, 244-48 (reviewing the Badham litigation); Lowell \& Craigie, California's Reapportionment Struggle: A Classic Clash Between Law and Politics, 2 J.L. \& Pol. 245 (1985) (recounting redistricting in California between the 1980 census and Badham); Political Gerrymandering: Badham v. Eu, Political Science Goes to Court, 18 PS 537 (1985) (symposium on the role of social science in redistricting litigation).

1s Since Baker v. Carr, 369 U.S. 186 (1962), redistricting litigation has run in decennial cycles tied to the U.S. Census. See U.S. ConST. art I, $\S 2$, cl. 3 ; see also Note, supra note 10 , at 1433 n.41 (arguing that states are required to use federal census figures in redistricting).

${ }_{16}$ See Gurwitt, supra note 8, at 1642. Georgetown University Law Professor Roy Schotland has described Davis as " 'literally inviting' an appeal by California Republicans ... ."Justices Uphold GOP Gerrymandering, Say Suits Can Challenge Such Practice, Wall St. J., July 1, 1986, at 4, col. 2; see also Gerrymander Test Looms: California GOP Will Base Suit to Invalidate Democrat-Drawn Districts on New Court Ruling, Christian Sci. Monitor, July 2, 1986, at 3, col. 3 (reporting statement by Frank Fahrenkopf, Republican national chairman, that Davis had opened the way to California challenge); Decision by High Court Likely to Refuel Debate on California Districting, L.A. Times, July 1, 1986, at 3, col. 5 (statement by Rep. William Thomas (R-California) that California redistricting suit would now proceed); G.O.P. Plans, supra note 8, at A17, col. 2 (reporting that Republican Party plans to use Davis in an attempt to overturn California plan). Needless to say, California Republicans have accepted the invitation to proceed. See Hess, supra note 5, at 248 (examining the impact of the Davis decision on the Badham litigation); Republicans Test, supra note 8 , at 1 , col. 2 (discussing the re-opening of Badham in United States District Court).

${ }_{17}$ See Court's Ruling Spurs Party Fight for Legislatures, N.Y. Times, July 2, 1986, at B6, col. 4 (analyzing legal and political strategies of parties in light of Davis 
In view of past precedent, Davis is the latest step in a progression toward proportional representation. ${ }^{18}$ This progression runs from Colegrove v. Green ${ }^{19}$ in 1946 through Baker v. Carr ${ }^{20}$ in 1962 and Reynolds $v$. Sims ${ }^{21}$ in 1964. A constitutional requirement of proportional representation, however, is inconsistent with republicanism and pluralism. ${ }^{22}$ Cognizant of this tension, yet propelled by the logic of the equally effective vote, the Davis Court held that political gerrymandering was justiciable. ${ }^{23}$ The majority of six, however, failed to reach a consensus on how to apply the equal protection standards of discriminatory intent and effects as brakes to prevent a complete slide to proportional representation. ${ }^{24}$ Justice White, for three other members of the Court, offered a "nebulous" concept of "consistent degradation" and hinted that courts should presume a legislative intent to gerrymander. Justice Powell, for himself and Justice Stevens, argued for a contextual approach that relies on an objective standard for reviewing legislative purpose. Both opinions, however, refer to the subjective motivations of legislators. ${ }^{25}$ Yet this motivational analysis is unnecessary because the objective context in which legislation is adopted, not the subjective motivations of particular legislators, is determinative. ${ }^{28}$ Moreover, a subjective approach raises troublesome questions of proof. In particular, legislators will legitimately exercise any speech or debate

and in anticipation of the 1990 census); Battle Lines Drawn for 1991: Outcome of Redistricting Fight May Determine Control of House, Wash. Post, Oct. 13, 1985, at A4, col. 1 (same). Notwithstanding the potential impact of Davis, a recent study suggests that a redistricting dispute in a given state is a function of single-party control of the process, the voting rule for adopting the redistricting plan, and the degree of political competitiveness within the state legislature. See Cain \& Campagna, Predicting Partisan Redistricting Disputes, 12 LEGIS. STUD. Q. 265, 266-67 (1987).

18 See Comment, The Supreme Court and Congressional Apportionment: Slippery Slope to Equal Representation Gerrymandering, 38 RuTGERS L. REv. 109, 110 (1985).

18328 U.S. 549 (1946).

20369 U.S. 186 (1962).

21377 U.S. 533 (1964).

22 See infra notes 153-71 and accompanying text.

${ }^{23}$ See Davis, 106 S. Ct. at 2806 (Brennan, White, Marshall, Blackmun, Powell \& Stevens, JJ.).

24 Cf. Lowenstein, supra note 5, at 4-5 (arguing that the six-judge Davis holding on justiciability "implied nothing about whether allegations of partisan gerrymandering ever would give rise to a substantively valid constitutional claim").

${ }^{23}$ Compare Davis, 106 S. Ct. at 2807-12 (Brennan, White, Marshall \& Blackmun, JJ.) (stressing that a lack of proportional representation does not prove unconstitutional discrimination and evidence of intent must be shown) with id. at 2832 (Powell \& Stevens, JJ., concurring and dissenting) (calling for application of an objective standard that examines the purposes for which the apportionment law was adopted).

${ }^{26}$ See Palmer v. Thompson, 403 U.S. 217, 224-26 (1971) (discussing the pitfalls of a subjective approach to equal protection analysis); see also infra notes 306-07 and accompanying text (arguing that the subjective motives of legislators are irrelevant). 
privilege based on separation of powers to avoid testifying as to their motives. Consequently, the Court should treat references to subjective motivation in Davis as dicta and instead attempt to establish an objective standard against which to measure legislative purpose.

This Comment is divided into four parts. Part I reviews pre-Davis redistricting litigation. This historical discussion illustrates that Davis continues on the path toward proportional representation that was set out in early redistricting litigation. Part II reconciles Davis, proportional representation, and constitutional theory. The concept of the equally effective vote strongly influenced the outcome in Davis, yet the Constitution does not mandate proportional representation. The Court in Davis thus used equal protection standards to paper over this gap. Part III examines the speech or debate clause strategy state legislators will likely use to try to avoid the subjective considerations in Davis. The purpose behind the speech or debate clause is to prevent the other two branches of government from interfering in legislative functions. Finally, Part IV argues that the Court should abandon references to subjective motivation of legislators in Davis and instead focus on an objective approach to legislative purpose.

\section{Pre-Davis Redistricting Litigation}

An understanding of pre-Davis redistricting litigation is necessary to understand the rationales supporting the three groupings in Davis $v$. Bandemer: ${ }^{27}$ the plurality opinion, written by Justice White and joined by Justices Brennan, Marshall, and Blackmun; Justice Powell's opinion, in which Justice Stevens joined; and Justice O'Connor's opinion, joined by Chief Justice Burger and Justice Rehnquist. This Comment divides the pre-Davis litigation into four categories: first, the "early" litigation from Colegrove v. Green ${ }^{28}$ to Baker v. Carr; ${ }^{29}$ second, redistricting litigation based on racial gerrymandering; third, redistricting litigation based on one person-one vote "numerical gerrymandering"; and fourth, redistricting litigation based on political gerrymandering. These categories parallel the analysis in Davis itself; the first addresses the justiciability issue ${ }^{30}$ and the remaining three address the equal protection issue. ${ }^{31}$

\footnotetext{
27106 S. Ct. 2797 (1986).

28328 U.S. 549 (1946).

29369 U.S. 186 (1962).

30 See infra notes 143-84 and accompanying text.

31 See infra notes 185-224 and accompanying text.
} 


\section{A. From Colegrove v. Green to Baker v. Carr}

Although the Court had considered redistricting questions in statutory contexts, ${ }^{32}$ the first claim that a congressional districting plan violated the equal protection clause did not come until 1946. In Colegrove, a badly divided Court ${ }^{33}$ rejected the claim of a Northwestern University political scientist that a forty-year-old Illinois congressional scheme in which the population of the plaintiff's district was eight times that of another district was unconstitutional. ${ }^{34}$

Justice Frankfurter, writing for himself and Justices Reed and Burton, held that redistricting was a political question: "[c]ourts ought not to enter this political thicket. The remedy for unfairness in districting is to secure State legislatures that will apportion properly, or to invoke the ample powers of Congress."35 In particular, Justice Frankfurter noted the "want of equity"36 and postulated that the plaintiff's claim was a guarantee clause ${ }^{\mathbf{3 7}}$ claim rather than an equal protection

32 See, e.g., Wood v. Broom, 287 U.S. 1, 8 (1932) (holding that the provisions of the Reapportionment Act of 1911, ch. 5, 37 Stat. 13, were not reenacted by the Reapportionment Act of 1929, ch. 28, 46 Stat. 21); Carroll v. Becker, 285 U.S. 380, 381-82 (1932) (holding that if the number of representatives from a state in Congress was reduced by the Reapportionment Act of 1929 and the state never redistricted, then the state had to conduct at-large elections); Koenig v. Flynn, 285 U.S. 375, 379 (1932) (sustaining the right of a governor to veto a redistricting scheme if the governor has veto power generally); Smiley v. Holm, 285 U.S. 355, 373-74 (1932) (deciding applicability of 1911 Reapportionment Act). See generally R. Hanson, The Political THICKET 44 (1966) (offering background on early redistricting litigation); Carpeneti, Legislative Apportionment: Multimember Districts and Fair Represenation, $120 \mathrm{U}$. PA. L. Rev. 666, 666 n.2 (1972) (same).

${ }^{33}$ Justice Frankfurter wrote for himself and Justices Reed and Burton. See Colegrove, 328 U.S. at 550. Justice Rutledge concurred. See id. at 564. Justice Black wrote in dissent for himself and Justices Douglas and Murphy. See id. at 566. Chief Justice Stone heard argument and participated in the conference but died before the decision was announced. Justice Jackson was prosecuting war criminals at Nuremberg. See R. Hanson, supra note 32, at 43-44; Friedelbaum, Baker v. Carr: The New Doctrine of Judicial Intervention and Its Implications for American Federalism, 29 U. CHI. L. REv. 673, 677 (1962).

34 See Colegrove v. Green, 64 F. Supp. 632, 634 (N.D. Ill. 1945), affd, 328 U.S. 549,556 (1946); R. Hanson, supra note 32, at 43. See generally Baker, Judicial Determination of Political Gerrymandering: A "Totality of Circumstances" Approach, 3 J.L. \& Pol. 1, 2 (1986) (analyzing "status quo" gerrymanders that result from the failure to reapportion after population shifts).

${ }^{36}$ Colegrove, 328 U.S. at 556. Hanson notes that six of the seven Colegrove justices, including "the high court's high priest of judicial self-restraint," Justice Frankfurter, had been appointed by President Roosevelt, hardly an enthusiast of judicial intervention. See R. Hanson, supra note 32, at 45; cf. Davis, $106 \mathrm{~S}$. Ct. at 2818-22 (O'Connor, J., concurring in the judgment) (maintaining that partisan gerrymandering is a nonjusticiable political question).

${ }^{36}$ Colegrove, 328 U.S. at 551; see also Rogowski, Representation in Political Theory and in Law, 91 ErHics 395, 415 (1981) (analyzing Frankfurter's decision).

37 The guarantee clause promise of a republican government, see U.S. CoNST. art. 
claim. ${ }^{38}$

Justices Black, Douglas, and Murphy strongly disagreed. Justice Black found for the plaintiffs both on equal protection and article I grounds. Noting the gross disparity among the populations of congressional districts and the failure of Illinois to reapportion in forty years, Justice Black viewed equal protection as protecting the right to an equally effective vote in the election of Congress. ${ }^{39}$ Justice Black buttressed the right to an equally effective vote by referring to article I, which provides that congressmen are chosen by the people: "It thus gives those qualified a right to vote and a right to have their vote counted."40

Justice Rutledge's concurrence provided the deciding vote in Colegrove. Justice Rutledge felt that Smiley $v$. Holm ${ }^{41}$ required the Court to hold that redistricting was justiciable, thus disagreeing with Justice Frankfurter on the political question issue. ${ }^{42}$ Because he was concerned, however, with the practical impact of holding for the plaintiffs with congressional elections approaching, Justice Rutledge held for the

I, $\S 4$, is nonjusticiable and enforceable only by Congress. See Coleman v. Miller, 307 U.S. 433, $445-46$ (1939); Georgia v. Stanton, 73 U.S. (6 Wall.) 50, 77 (1867); Luther v. Borden, 48 U.S. (7 How.) 1, $42-47$ (1849). But see J. Ely, Democracy AND DisTRUST 118-23 (1980) (concluding that the equal protection and guarantee clauses together justify active judicial review of apportionment); Bonfield, Baker v. Carr: New Light on the Constitutional Guarantee of Republican Government, 50 Calif. L. REv. 245, 263 (1963) (arguing that the guarantee clause, not the equal protection clause, should have been the basis of redistricting litigation); Bork, Neutral Principles and Some First Amendment Problems, 47 IND. L.J. 1, 18-19 (1971) (arguing that only the value-neutral requirements of democratic process, embodied in the guarantee clause, could make a legislative apportionment unconstitutional); Note, Political Rights as Political Questions: The Paradox of Luther v. Borden, 100 HARv. L. REv. 1125, 1144 (1987) (criticizing the Luther Court for "politicizing the republican conception of a universal right to political participation"); Comment, The Guarantee of Republican Government, Proposals for Judicial Review, 54 U. CHI. L. REv. 208, 226-32 (1987) (arguing that the Framers understood republican government as a structural remedy for both factionalism and authoritarianism); Note, The Rule of Law and the States: $A$ New Interpretation of the Guarantee Clause, 93 Yal. L.J. 561, 579-80 (1984) [hereinafter Rule of $L a w]$ (advocating the reinvigoration of the guarantee clause).

s8 Colegrove, 328 U.S. at 556 (citing Pacific States Tel. \& Tel. v. Oregon, 223 U.S. 118 (1912)).

38 Id. at 574 (Black, J., dissenting); cf. Davis, 106 S. Ct. at 2805-07 (quoting favorably the "effectiveness" language in Reynolds v. Sims, 377 U.S. 533, 565-66 (1964)).

${ }^{10}$ Colegrove, 328 U.S. at 570 (Black, J., dissenting); see also Rogowski, supra note 36, at 414-16 (analyzing Justice Black's use of the ballot fraud cases, United States v. Mosley, 238 .U.S. 383 (1915), and United States v. Saylor, 322 U.S. 385 (1944), to sustain the justiciability of the redistricting issue).

11285 U.S. 355 (1932) (deciding the applicability of the Reapportionment Act of 1911 , ch. 5, 37 Stat. 13, which required congressional districts to be compact and contiguous).

${ }^{42}$ See Colegrove, 328 U.S. at 564-65 (Rutledge, J., concurring). 
defendants on equitable, but not constitutional, grounds. ${ }^{43}$

Despite the support of only three justices in Colegrove, the new postwar mobility in American society as reflected in the 1950 census, ${ }^{44}$ and a series of critical law review articles, ${ }^{45}$ Justice Frankfurter's view seemed ascendant in the late 1940's and the 1950's. Between 1946 and 1962 , the Court summarily refused to consider eleven redistricting cases, usually citing Colegrove. ${ }^{48}$

Nevertheless, pressure built. In Gomillion v. Lightfoot, ${ }^{47}$ a unani-

43 See id. at 565-66 (Rutledge, J., concurring).

14 See Baker, Whatever Happened to the Reapportionment Revolution in the United States?, in Electoral Laws and Their Political Consequences 257, 259 (B. Grofman \& A. Lijphart eds. 1986) [hereinafter Electoral. Laws]. See generally G. Baker, The Reapportionment Revolution: Representation, Political Power, AND THE SUPREMe CourT 23-98 (1966) (detailing the degree of malapportionment at both the state and local levels prior to Baker); Tyler, Court Versus Legislature, 27 LaW \& Contemp. Probs. 390, 402-03 (1962) (same).

is E.g., Celler, Congressional Apportionment-Past, Present, and Future, 17 LAw \& Contemp. ProBs. 268, 273-74 (1952) (endorsing a proposed congressional bill that would require that the population of any congressional district not vary more than $15 \%$ above or below the average population for each district within the state); Lewis, Legislative Apportionment and the Federal Courts, 71 HARv. L. REv. 1057, 1095-98 (1958) (concluding that the courts should provide moral leadership to resolve the effects of malapportionment); Tabor, The Gerrymandering of State and Federal Legislative Districts, 16 MD. L. Rev. 277, 302 (1956) (attributing failed attempts to secure effective judicial relief against gerrymandering to the reluctance of courts to intervene). See generally R. HANSON, supra note 32, at 47 (collecting law review articles critical of Frankfurter's decision in Colegrove).

46 See Matthews v. Handley, 361 U.S. 127 (1959) (mem.), aff'g 179 F. Supp. 470 (D. Ind. 1959) (sustaining motion to dismiss); Hartsfield v. Sloan, 357 U.S. 916 (1958) (mem.) (denying writ of mandamus to the United States District Court for the Northern District of Georgia); Radford v. Gary, 352 U.S. 991 (1956) (mem.), aff'g 145 F. Supp. 541 (W.D. Okla. 1956) (sustaining motion to dismiss); Kidd v. McCanless, 352 U.S. 920 (1956) (mem.), dismissing appeal from 200 Tenn. 273, 292 S.W.2d 40 (1956) (refusing to declare redistricting act unconstitutional); Anderson v. Jordan, 343 U.S. 912 (1952) (mem.) (dismissing appeal from the California Supreme Court); Cox v. Peters, 342 U.S. 936 (1952) (mem.), dismissing appeal from $208 \mathrm{Ga} .498,67$ S.E.2d 579 (1951) (refusing to consider constitutionality of county-unit system); Tedesco v. Board of Supervisors of Elections, 339 U.S. 940 (1950) (mem.), dismissing appeal from 43 So. 2d 514 (La. Ct. App. 1949) (refusing to upset districting of city council seats); MacDougall v. Green, 335 U.S. 281 (1948) (per curiam) (affirming the denial of an injunction for want of jurisdiction); Colegrove v. Barrett, 330 U.S. 804 (1947) (mem.) (dismissing appeal from the United States District Court for the Northern District of Illinois); Turman v. Duckworth, 329 U.S. 675 (1946) (mem.), affg G8 F. Supp. 744 (N.D. Ga. 1946) (upholding county-unit system); Cook v. Fortson, 329 U.S. 675 (1946) (mem.), dismissing appeal from 68 F. Supp. 624 (N.D. Ga. 1946) (upholding county-unit system); see also R. HANSON, supra note 32, at 46 (analyzing pre-Baker judicial interpretations of Colegrove); Carpeneti, supra note 32, at 666 n.1 (same); Friedelbaum, supra note 33, at 680-84 (same); Lucas, Legislative Apportionment and Representative Government: The Meaning of Baker v. Carr, 61 MicH. L. REv. 711, 717-41 (same). But see Gomillion v. Lightfoot, 364 U.S. 339 (1960) (holding that racial gerrymandering violates the fifteenth amendment); infra text accompanying note 73 (discussing Gomillion).

47364 U.S. 339 (1960). 
mous Court held that the fifteenth amendment prohibited racial gerrymandering. While Justice Frankfurter took pains to distinguish the fifteenth amendment analysis in Gomillion from Colegrove, ${ }^{48}$ the fact remained that the Gomillion Court had treated redistricting as justiciable. ${ }^{48}$ Moreover, the composition of the Court had changed dramatically since Colegrove. Justice Frankfurter's allies, Justices Burton and Reed, had retired and Chief Justice Stone and Justice Jackson were dead. Taking their seats were Chief Justice Warren and Justices Brennan, Clark, and Stewart. ${ }^{50}$

The Warren Court's decision to reconsider the justiciability question was made even easier by the intervention of the Eisenhower and Kennedy Solicitors General on the plaintiffs' behalf. ${ }^{51}$ Thus when the Court agreed to review Baker v. Carr ${ }^{52}$ the Court had a case in which the plaintiffs had exhausted state legal remedies, were supported by the weight of legal and political commentary, and had the assistance of the executive branch. ${ }^{\text {s3 }}$

Justice Brennan wrote the majority opinion in Baker, joined by Chief Justice Warren and Justices Stewart, Douglas, Black, and Clark. ${ }^{\mathbf{5}}$ Justice Brennan's opinion began by reinterpreting Colegrove as conferring subject matter jurisdiction based on Justice Black's dissent and Justice Rutledge's concurrence. ${ }^{.5}$ As Justice Brennan noted, subject matter jurisdiction and justiciability are different concepts. Subject mat-

4 See id. at 346-47; see also R. HANSON, supra note 32, at 51 (noting Frankfurter's efforts to distinguish the fourteenth and fifteenth amendment issues); Lucas, Dragon in the Thicket: A Perusal of Gomillion v. Lightfoot, 1961 SuP. CT. REv. 194, 232-34 (arguing that the fourteenth-fifteenth amendment distinction goes to the scope of equal protection, not justiciability); cf. Davis, $106 \mathrm{~S}$. Ct. at 2820 (O'Connor, J., concurring in the judgment) (distinguishing between partisan and racial gerrymandering). But cf. id. at 2806-07 (rejecting Justice O'Connor's distinctions); Leading Cases, supra note 5, at 159 (calling Justice O'Connor's distinctions "untenable").

18 Justice Whitaker, concurring, stated that Brown v. Board of Educ., 347 U.S. 483 (1954), not Colegrove, was dispositive. See Gomillion, 364 U.S. at 349 (Whitaker, J., concurring). Justice Douglas joined the decision but explicitly adhered to his dissent in Colegrove. See id, at 348 (Douglas, J., concurring).

${ }_{50}$ Neal, Baker v. Carr: Politics in Search of Law, 1962 Sup. CT. Rev. 252, 257 (noting the change of personnel on the Court).

${ }^{81}$ See R. Hanson, supra note 32, at 52-54 (suggesting that Vice President Nixon played a critical role in allowing President Eisenhower's Solicitor General to file a brief as amicus curiae); Lewis, supra note 45, at 1078 (criticizing the way in which Colegrove was litigated).

s2 364 U.S. 898 (1960), noting prob. juris. over 179 F. Supp. 824 (M.D. Tenn. 1959).

ss See R. Hanson, supra note 32, at 52-54 (explaining how Baker was readied for the Court); Friedelbaum, supra note 33, at 688-89 (same).

54 Justice Whitaker did not participate, making the decision 6-2. See Baker, 369 U.S. at 237.

so See id. at 202-04; of. Lucas, supra note 48, at 716-17 (criticizing Justice Brennan's manipulation of the Colegrove dissent and concurrence). 
ter jurisdiction exists if "the matter set forth in the complaint does arise under the Constitution and is within 28 U.S.C. $\S 1343 . "{ }^{26}$ The plaintiffs had standing, ${ }^{57}$ and the guarantee clause did not shield redistricting from judicial review. ${ }^{58}$ Most importantly, redistricting presented a justiciable question because it did not implicate concerns such as separation of powers or lack of "judicially discoverable and manageable standards" inherent in other political question cases. ${ }^{80}$

But Justice Brennan, citing the familiarity of the lower courts with equal protection analysis, ${ }^{80}$ articulated no standards for lower courts to follow. Justices Clark ${ }^{61}$ and Douglas ${ }^{62}$ were not satisfied with this result, however, and consequently articulated their own standards. ${ }^{63}$ Treading the narrow ground, in contrast, Justice Stewart in a separate concurrence tried to limit the scope of Justice Brennan's opinion to justiciability. ${ }^{64}$

so Baker, 369 at 199.

${ }^{57}$ Id. at 204-08. The plaintiffs were residents of counties that were underrepresented in the state legislature. Id.; $c f$. Neal, supra note 50, at 271-74 (raising the issue as to whether the Court reached the right conclusion vis-à-vis standing since plaintiffs in redistricting suits may not be representative of the electorate and defendants are clearly nominal). But cf. supra note 9 (demonstrating the intervention of a wide range of groups in Davis).

s8 See Baker, 369 U.S. at 228-29 (holding that the guarantee clause regulates the relationships among the branches of the federal government and not the relationship between the states and the federal judiciary).

B9 Id. at 217; cf. Davis, 106 S. Ct. at 2805-06 (citing Reynolds v. Sims, 377 U.S. 533, 557-61 (1964)).

so See Baker, 369 U.S. at 226. Compare G. BAKer, supra note 44, at 123-24 (calling Justice Brennan's move "calculated and perceptive" as it afforded the different state and lower federal courts the opportunity to experiment) and McKay, Political Thickets and Crazy Quilts: Reapportionment and Equal Protection, 61 Mich. L. REv. 645, 650 (1963) (stating that "postponement [of the establishment of standards] was not only permissible, but born of the wisdom of judicial experience") with Dixon, Legislative Apportionment and the Federal Constitution, 27 LAw \& ConTEMP. PROBS. 329, 355 (1962) (castigating Justice Brennan for not providing standards) and McCloskey, The Supreme Court, 1966 Term-Foreword: The Reapportionment Case, 76 HaRv. L. Rev. 54, 63 (1962) (noting that Justice Brennan's decision rested on the premise that redistricting was a justiciable issue because manageable standards did exist, yet Justice Brennan failed to identify them).

Reaction to Davis has been similarly divided. Compare Lowenstein, supra note 5, at 3 (stating that the criticism that Justice White did not adequatelyset forth standards is "misplaced") with Leading Cases, supra note 5, at 154 (arguing that "the Court's failure to provide lower courts with clear standards . . . seriously undermines the decision's practical impact").

6I See Baker, 369 U.S. at 259-64 (Clark, J., concurring).

${ }^{62}$ See id. at 250 n.5 (Douglas, J., concurring).

os See Rogowski, supra note 36, at 417-18 (viewing Douglas as demanding absolute equality in contrast to Clark's demanding no arbitrary inequality); cf. Davis, 106 S. Ct. at 2831 (Powell, J., concurring and dissenting) ("The final and most basic flaw in the plurality's opinion is its failure to enunciate any standard that affords guidance to legislatures and courts.").

${ }_{64}$ See Baker, 369 U.S. at 265-66 (Stewart, J., concurring). 
Justice Frankfurter, on the other hand, attacked the majority in a bitter dissent for ignoring precedent, ${ }^{66}$ entering a "mathematical quagmire," judiciary." under a different label." ${ }^{\text {"88 }}$ Expressing concern over the public's perception of the Court's role in politics, Justice Harlan joined Justice Frankfurter ${ }^{68} \mathrm{He}$, too, feared that, the Court having once entered the thicket of redistricting by answering the justiciability question, every attempt to find a way. out would only lead to deeper involvement. ${ }^{70}$ It did. ${ }^{71}$ Critics say the same today about political gerrymandering such as that addressed in Davis. ${ }^{72}$ Consequently, an understanding of the equal pro-

65 See id. at 277-80 (Frankfurter, J., dissenting); cf. Davis, 106 S. Ct. at 2818 (O'Connor, J., concurring in the judgment) (criticizing the plurality for ignoring precedent holding that political gerrymandering claims are nonjusticiable political questions).

${ }_{68}$ Baker, 369 U.S. at 268 (Frankfurter, J., dissenting); cf. Davis, $106 \mathrm{~S}$. Ct. at 2818 (O'Connor, J., concurring in the judgment) (criticizing the plurality for not articulating manageable standards in its analysis of gerrymandering claims under the equal protection clause).

${ }^{67}$ Baker, 369 U.S. at 268 (Frankfurter, J., dissenting); cf. Davis, 106 S. Ct. at 2818 (O'Connor, J., concurring in the judgment) ("TT]he losing party or the losing group of legislators in every reapportionment will now be invited to fight the battle anew in federal court.").

68 Baker, 369 U.S. at 297 (Frankfurter, J., dissenting); see also supra notes 37-38 and accompanying text; $c f$. McKay, supra note 60 , at 650 (maintaining that the jurisdiction, justiciability, and standing issues merely mask "the basic disagreement on whether courts can act profitably in the review of legislative arrangements").

6o See Baker, 369 U.S. at 340 (Harlan, J., dissenting); see also McKay, supra note 60 , at 651 ("There is considerable justification for reading . . . the . . Harlan dissent[] for the proposition that no malapportionment, however severe, should be held to violate the equal protection clause."); Rogowski, supra note 36, at 426-27 (criticizing Harlan's jurisprudence on redistricting as denying any right to representation except to the extent created by Congress); cf. Davis, $106 \mathrm{~S}$. Ct. at 2817 (O'Connor, J., concurring in the judgment) (criticizing the plurality for "inject[ing] the courts into the most heated partisan issues"); id. at 2822 (citing Shapiro, Gerrymandering, Unfairness, and the Supreme Court, 33 UCLA L. REv. 227, 253-54 (1985) (warning that the appearance of judicial partisanship will be far greater in districting decisions than in a Baker-like reapportionment analysis)). But cf. Dovenbarger, Democracy and Distemper: An Examination of the Sources of Judicial Distress in State Legislative Apportionment Cases, 18 InD. L. REv. 885, 885-86 (1985) (asserting that the Court's involvement in the redistricting process probably enhanced its standing in the public's eyes); McCloskey, supra note 60, at 59 (same); Comment, supra note 1, at 983 (same).

${ }_{70}$ See Moeller, The Supreme Court's Quest for Fair Politics, 1 Const. ComMENTARY 203, 210-11 (1984) (pursuing fairness in its analysis of politics has "led the Court into a quagmire"); Rogowski, supra note 36, at 426-30 (analyzing the Court's slippery slope from no right to representation to the right to equally powerful (proportional) representation). But see Davis, 106 S. Ct. at 2809 (adamantly denying any constitutional right to proportional representation).

${ }^{71}$ See $\mathrm{R}$. HANSON supra note 32, at 57-58 (describing the reaction to Baker as "the legal blitz"); Baker, supra note 44, at 258 (noting the "flood-tide of litigation" after Baker); McCloskey, supra note 60 , at 56 \& n.14 (describing the immediate response as "nothing short of astonishing").

${ }_{72}$ See, e.g., Davis, $106 \mathrm{~S}$. Ct. at 2822 (O'Connor, J., concurring in the judgment) 
tection standards developed in the post-Baker, pre-Davis era is necessary to understand both the plurality's attempt at promulgating standards in Davis and the outcome of future litigation.

\section{B. Racial Gerrymandering}

The seminal racial gerrymandering case, Gomillion v. Lightfoot, actually predated Baker. In Gomillion, the Court allowed a fifteenth amendment challenge to an attempt by the Alabama legislature to redraw the boundaries of the city of Tuskegee so as to exclude virtually all black voters from the city. ${ }^{73}$ Since Gomillion, the Court has struck down multimember districting schemes that were intentionally designed to prevent minorities from holding office. ${ }^{74}$ Multimember districts are not, however, unconstitutional per se because minorities also lose elections for reasons unrelated to unconstitutional discrimination. ${ }^{25}$ To establish a successful claim that racial gerrymandering violates the equal protection clause, a member of an identifiable group must show both a racially discriminatory purpose and a racially discriminatory effect; a

(finding "intractable difficulties in deriving a judicially manageable standard from the Equal Protection Clause for adjudicating political gerrymandering claims"); Shapiro, supra note 69, at 253-54 (envisioning "a continuing stream of cases in which the Court suffers increasing losses to its reputation for reasoned, neutral decision making").

${ }^{73}$ See Gomillion, 364 U.S. at 340-42.

74 See, e.g., Rogers v. Lodge, 458 U.S. 613, 622 (1982) ("We are . . . unconvinced that we should disturb the District Court's finding that the at-large system in Burke County was being maintained for the invidious purpose of diluting the voting strength of the black population."); White v. Regester, 412 U.S. 755, 765-67 (1973) (sustaining the District Court's judgment that Dallas and Bexar County multimember districts excluded minorities from meaningful participation in the political process); $c f$. Blacksher \& Menefee, From Reynolds v. Sims to City of Mobile v. Bolden: Have the White Suburbs Commandeered the Fifteenth Amendment?, 34 Hastings L.J. 1, 18-26 (1982) (criticizing the Court's approach to racial gerrymandering after Reynolds).

${ }_{75}$ See City of Mobile v. Bolden, 446 U.S. 55, 73 (1980) ("It may be that Negro candidates have been defeated, but that fact alone does not work a constitutional deprivation."); Whitcomb v. Chavis, 403 U.S. 124, 154-55 (1971) ("The mere fact that one interest group . . . has found itself outvoted . . . provides no basis for invoking constitutional remedies where . . there is no indication that this segment of the population is being denied access to the political system."); Burns v. Richardson, 384 U.S. 73, 88 (1966) (Multimember districting constitutes invidious discrimination only where " 'designedly or otherwise, a multi-member constituency apportionment scheme, under the circumstances of a particular case, would operate to minimize or cancel out the voting strength of racial or political elements of the voting population.' " (quoting Fortson v. Dorsey, 379 U.S. 433, 439 (1965))); see also Engstrom \& McDonald, The Effect of AtLarge Versus District Elections on Racial Representation in U.S. Municipalities, in EleGTORAL Laws, supra note 44, at 203 (suggesting that the original purpose of atlarge elections was to promote a more republican, as opposed to pluralist, view of municipal government); Lineberry \& Fowler, Reformism and Public Policies in American Cities, 61 AM. POL. SCI. REv. 701, 715 (1967) (suggesting that at-large, nonpartisan elections "decrease the salience of 'private regarding' demands by increasing the relative political power of 'public regarding' agencies like the local press"). 
mere showing of disparate impact is insufficient. ${ }^{76}$ Something less than proof perfect of intent is sufficient, however, because the existence of "an invidious discriminatory purpose may often be inferred from the totality. of the relevant facts." ${ }^{277}$ Among the factors ${ }^{78}$ the Court has found relevant in ascertaining racially invidious intent are the "impact of past discrimination on the ability of blacks to participate," "exclusion from the political process," "un "unresponsive[ness] and insensitiv[ity] to the needs of the black community," cioeconomic status of . . . blacks." 82 Finally, the plaintiffs still must show a racially discriminatory effect. ${ }^{83}$

On the other hand, the Court has never struck down a singlemember redistricting scheme on the basis of racial gerrymandering despite having had the opportunity. ${ }^{84}$ In fact, the Court has stated that when a district court develops a redistricting plan as a remedy to state inaction, single-member districts are preferable. ${ }^{85}$

After the Court reaffirmed in City of Mobile $v$. Bolden ${ }^{86}$ that an

${ }^{76}$ See, e.g., Rogers, 458 U.S. at 617 ("[A] showing of discriminatory intent has long been required in all types of equal protection cases charging racial discrimination."); City of Mobile, 446 U.S. at 66-67 ("[O]nly if there is purposeful discrimination can there be a violation of the Equal Protection Clause of the Fourteenth Amendment."); $c f$. Davis, 106 S. Ct. at 2808 ("[I]n order to succeed the Bandemer plaintiffs were required to prove both intentional discrimination against an identifiable political group and an actual discriminatory effect on that group."). (1976)).

${ }^{27}$ Rogers, 458 U.S. at 618 (quoting Washington v. Davis, 426 U.S. 229, 242

${ }^{78}$ Cf. Davis, 106 S. Ct. at 2831-32 (Powell, J., concurring and dissenting) (offering factors to consider in determining the existence of a partisan gerrymander).

79 Rogers, 458 U.S. at 624.

80 Id. at 625 .

${ }^{81} I d$.

82 Id. at 626.

83 See City of Mobile v. Bolden, 446 U.S. 55, 66-68 (1980); Whitcomb v. Chavis, 403 U.S. 124, 149 (1971).

84 See, e.g., United Jewish Organizations v. Carey, 430 U.S. 144, 167-68 (1977) (denying claim by Hasidic Jews whose community was politically divided to make a minority-dominated district); Wright v. Rockefeller, 376 U.S. 52, 58 (1964) (denying claim that New York legislature had racially segregated congressional districts in Manhattan); see also B. CAIN, The ReAPPoRtionment Puzzle 168-71 (1984) (discussing the "twin sins of dispersion and concentration" of minority groups in racial redistricting); Dixon, Fair Criteria and Procedures for Establishing Legislative Districts, in REPRESENTATION AND REDISTRICTING Issues 7, 9 (1982) (recognizing that singlemember redistricting is a zero-sum game).

${ }_{85}$ See City of Mobile, 446 U.S. at 66 n.12; Connor v. Finch, 431 U.S. 407, 415 (1977); Mahan v. Howell, 410 U.S. 315, 333 (1973); Connor v. Johnson, 402 U.S. 690,692 (1971).

${ }^{86} 446$ U.S. 55, 66-68 (1980). For criticism of City of Mobile, see, for example, Copeland, The Status of Minority Voting Rights: A Look at Section V Preclearance Protections and Recent Decisions Affecting Multi-Member Voting Districts, 28 How. L.J. 417, 428 (1985) (noting the "fragility" of a decision characterized by five separate opinions); Comment, City of Mobile v. Bolden: A Setback in the Fight Against Dis- 
invidious intent is necessary for an equal protection claim, Congress recognized the near impossibility of proof absent the "smoking gun."87 Hence Congress, exercising its powers under the civil rights amendments, redrafted section 2 of the Voting Rights Act of $1965^{88}$ to eliminate the need for minority plaintiffs to prove an invidious intent. ${ }^{89} \mathrm{Al}-$ though the amended section 2 directs courts to consider "the totality of circumstances" in determining whether or not political participation is open to members of a class protected by the Act, the amendment seemingly contradicts itself by explicitly eschewing proportional representation. ${ }^{90}$ Consequently, future litigation involving racial gerrymandering is much more likely to arise under section 2 of the Voting Rights Act than under the equal protection clause. ${ }^{91}$ What racial gerrymandering and political gerrymandering ostensibly have in common, however, is an identifiable group that is the intended target of unconstitutional discrimination..$^{92}$

crimination, 47 BRookLyN L. Rev. 169, 173 (1980) (charging that City of Mobile "effectively undercuts" constitutional challenges of vote-dilution schemes); Note, City of Mobile v. Bolden: Voter Dilution and New Intent Requirements Under the Fifteenth and Fourteenth Amendments, 18 Hous. L. REv. 611, 611 (1981) (calling City of Mobile "a significant step backward").

87 See Blacksher, Drawing Single-Member Districts to Comply with the Voting Rights Amendments of 1982, 17 URB. LAw. 347, 350 (1985) (citing as a rare example Busbee v. Smith, 549 F. Supp. 494 (D.D.C. 1982) (three-judge court), affd mem., 459 U.S. 1166 (1983)); see also Blacksher \& Menefee, supra note 74, at 31-32 (describing the Senate Judiciary Committee's assessment that an intent test places an "unacceptable burden" on plaintiffs in voting discrimination cases).

In contrast, the Court did not wait for Congress in the area of criminal process. See Batson v. Kentucky, 106 S. Ct. 1712, 1720-21 (1985) (in applying the equal protection clause to the use of peremptory challenges in criminal jury trials, the Court rejected Swain v. Alabama, 380 U.S. 202 (1965), as setting an impossible burden of proof).

${ }^{88}$ See Voting Rights Act Amendments of 1982, Pub. L. No. 97-205, 96 Stat. 134 (codified at 42 U.S.C. \$ 1973(b) (1982)).

${ }^{89}$ See Thornburg v. Gingles, 106 S. Ct. 2752, 2762-64 (1986).

${ }^{80}$ See 42 U.S.C. \& 1973(b) (1982).

91 See Thornburg, $106 \mathrm{~S}$. Ct. at 2752 (challenging the use of multimember districts in North Carolina); see also Baker, supra note 44, at 269 (commenting on the role of the judiciary after the 1982 amendments); Blacksher, supra note 87, at 353-66 (analyzing standards for single-member districts after the 1982 amendments); Howard \& Howard, The Dilemma of the Voting Rights Act-Recognizing the Emerging Political Equality Norm, 83 Colum. L. REv. 1615, 1616 (1983) (arguing that the creation of minority-dominated "safe districts" serves the racial equality norm of the equal protection clause, but infringes on the political equality norm of the equal protection clause and U.S. Const. art. I, § 2); Note, Results of the Results Test: The Impact of the 1982 Amendments to Section 2 of the Voting Rights Act on Dilution Suits, 2 J.L. \& PoL. 341, 357-64 (1985) (analyzing the impact of the 1982 amendments).

${ }^{82}$ Compare Davis, $106 \mathrm{~S}$. Ct. at 2806 ("that the claim is submitted by a political group, rather than a racial group, does not distinguish it") with id. at 2820 (O'Connor, J., concurring in the judgment) (arguing that the Democratic and Republican parties, unlike racial minorities, are not discrete and insular groups). 


\section{Numerical Gerrymandering}

In the context of this Comment, "numerical gerrymandering" refers to redistricting plans in which the populations of different legislative districts within a state are unequal. ${ }^{93}$ Shortly after Baker, the Court declared in Wesberry $v$. Sanders" that "one person, one vote"95 governed in congressional redistricting, thus introducing the notion of "equal representation." "96 The Court expanded on equal representation

${ }^{83}$ Beyond the scope of this Comment are the three ultimate gerrymanders: 1) the electoral college, see Levinson, Gerrymandering and the Brooding Omnipresence of Proportional Representation: Why Won't It Go Away, 33 UCLA L. REv. 257, 279-81 (1985) (discussing unfairness in the operation of the electoral college); Still, Political Equality and Election Systems, 91 ETHICs 375, 392-93 (1981) (discussing how the electoral college fails to satisfy various criteria for political equality), 2) the United States Senate, see Lucas v. Forty-Fourth Gen. Assembly, 377 U.S. 713, 755 n.14 (1964) (Stewart, J., dissenting) (pointing out that, at that time, $17 \%$ of the population of the United States elected 52\% of United States senators); Levinson, supra, at 264 n.29 (noting the conflict between Reynolds v. Sims, 377 U.S. 533 (1964), requiring under the equal protection clause "substantially equal" representation, and the electoral process for the Senate), and 3) the apportionment of congressmen among the states, see M. Balinski \& H. Young, Fair Representation: MeEting the Ideal of One Man, One Vote 1-66, app. B at 157 (1982) (reviewing the various methods of apportioning seats in Congress among the states and applying the six major methods (Adams, Dean, Hill, Webster, Jefferson, and Hamilton) to 19 federal censuses from 1791 to 1970); Grofman, Criteria for Districting: A Social Science Perspective, 33 UCLA L. REv. 77, 88-89 (1985) (as of 1982, the ideal congressional district population in Nevada was 393,345, while that in South Dakota was 690,178); Note, supra note 10 , at 1432-34 (explaining how seats in Congress are apportioned).

Also beyond the scope of this Comment are inequalities generated by population undercounts. See Note, supra note 10, at 1463 (arguing that the Constitution requires statistical adjustments of actual census counts to compensate for undercounts); Note, Demography and Distrust: Constitutional Issues of the Federal Census, 94 HaRv. L. Rev. 841, 863 (1981) (arguing the Census Bureau should prepare adjusted statistics to account for differential undercounting).

94376 U.S. 1 (1964).

${ }^{85}$ Id. at 18 (citing Gray v. Sanders, 372 U.S. 368, 381 (1963) (overturning county-unit system of counting votes)). Although the Court originally used the phrase "one person, one vote" it has subsequently shifted back and forth between that phrase and "one man, one vote." See Note, Reapportionment: A Call for a Consistent Quantitative Standard, 70 Iowa L. Rev. 663, 663 n.3 (1985).

${ }^{96}$ Wesberry, 376 U.S. at 18 ("While it may not be possible to draw congressional districts with mathematical precision, that is no excuse for ignoring our Constitution's plain objective of making equal representation for equal numbers of people the fundamental goal for the House of Representatives."). Justice Black relied on article I, section 2 in reaching this conclusion. See id. at 7-8; see also Black, Representation in Law and Equity, in Nomos X: Representation 131, 134-36 (J. Pennock \& J. Chapman eds. 1968) (restating Justice Black's constitutional argument and concluding that it is more sensible than contrary arguments). But see Karcher v. Daggett, 462 U.S. 725, 745 (1983) (Stevens, J., concurring) (acknowledging Wesberry on stare decisis grounds but noting that article I, section 2, "says nothing about the composition of congressional districts within a state"); Wesberry, 376 U.S. at 30-45 (Harlan, J., dissenting) (disputing Justice Black's use of the Framers' intent and instead arguing that Wood v. Broom, 287 U.S. 1 (1932), and article I, section 4, left the matter to Congress); Auerbach, The 
in Reynolds $v$. Sims. ${ }^{97}$ Relying on the statement that " $[\mathrm{t}]$ he right to vote is personal","98 the Reynolds Court held that "the Equal Protection Clause requires that the seats in both houses of a bicameral state legislature must be apportioned on a population basis." "99 Elaborating on the purpose behind this right, the Court declared that "[f]ull and effective participation by all citizens in state government requires, therefore, that each citizen have an equally effective voice in the election of members of his state legislature."100

The pursuit of voter equality in Reynolds raised problems of mea-

Reapportionment Cases: One Person, One Vote-One Vote, One Value, 1964 Sup. CT. REv. 1, 5 ("Mr. Justice Black's effort to show that the Court's conclusion is compelled by the language of Article $I, \S 2$, read in the light of the intent of the Framers of the Constitution, is not convincing."); Carpenter, Wesberry v. Sanders: A Case of Oversimplification, 9 VILL. L. REv. 415, 417 (1964) ("Mr. Justice Black's forays into history can be painful."); Kauper, Some Comments on the Reapportionment Cases, $63 \mathrm{MICH}$. L. REv. 243, 247 (1964) (While there is a constitutionally protected right to vote, "[i]t is another thing to say that this right to vote furnishes the key to legislative apportionment problems."); Note, Beyond Wesberry: State Apportionment and Equal Protection, 39 N.Y.U. L. REv. 264, 265 (1964) ("In resting its decision upon section 2, the Court failed to establish precedent for state legislative apportionment cases, which must rest upon the equal protection clause.").

87377 U.S. 533 (1964); sêe alsó Black, supra note 96, at 132-33 (distinguishing between Reynolds, in which the Court ruled on state legislative districting, which is central to the structure of the state government (perhaps the primary state concern), and Wesberry, in which the Court ruled on districting for federal elections, a more appropriate subject for federal review).

${ }_{88}$ Reynolds, 377 U.S. at 561 (citing United States v. Bathgate, 246 U.S. 220, 227 (1918)); see also R. HANSON, supra note 32, at 76 (interpreting Reynolds and its companion case Lucas v. Forty-Fourth Gen. Assembly, 377 U.S. 713 (1964), as supporting the proposition that the right to vote is personal).

${ }^{90}$ Reynolds, 377 U.S. at 568. In particular, the Reynolds Court held that no analogy existed between the federal legislative structure and a state system in which each county had a least one member in the lower chamber, with the remaining members allocated by population, and had equal representation in the upper chamber, because the federal structure was a compromise made in "unique historical circumstances" to establish the union of formerly independent states, while the political structure of the states is merely an administrative convenience. See id. at 574-75; see also Lucas v. Forty-Fourth Gen. Assembly, 377 U.S. 713, 724-26, 738 nn.31-32 (1964) (striking down a Colorado redistricting scheme modeled after the federal plan by districting the lower chamber of the state legislature by population, but guaranteeing one state senator to each county in the upper chamber); J. FordHAM, The STATE LEGiSLATIVE INSTITUTION 30 (1959) (arguing that the federal analogy is inapplicable to state-created subdivisions); McKay, supra note 60 , at 690 (noting that the "Great Compromise" dealt with inter-, not intrastate, apportionment); Tyler, What is Representative Government?, NEw RePuBlic, July 16, 1962, at 15, 17 ("The 13 original states created the United States; the counties were created by the states."). There are arguments other than the federal analogy that could be used to defend bicameral legislatures having one body not representative of equally populated districts. See R. HANsoN, supra note 32, at 112-13.

100 Reynolds, 377 U.S. at 565; cf. Davis, 106 S. Ct. at 2806 (quoting Reynolds to support "the justiciability of claims going to the adequacy of representation in state legislatures"). 
surement and mathematics. ${ }^{101}$ In Wesberry, Justice Black had stressed absolute equality in congressional redistricting as a fundamental goal of the Constitution to be pursued despite possible mathematical imprecision. ${ }^{102}$ In contrast, Chief Justice Warren determined in Reynolds that in state redistricting "[m]athematical exactness or precision is hardly a workable constitutional requirement." ${ }^{\text {"103 }}$ Consequently, the Court expressed a willingness to accept small deviations as long as they advanced a rational state policy. ${ }^{104}$

An equal vote, however, is not necessarily an equally effective vote. $^{100}$ The effectiveness of any individual vote depends on the ability

101 See Backstrom, Problems of Implementing Redistricting, in REPRESENTATION AND REDISTRICTING Issues, supra note 84 , at $43,44-49$ (discussing the problems that arise in trying to attain mathematical equality in practical operation); see also Dixon, Representation Values and Reapportionment Practice: The Eschatology of "One-Man, One-Vote", in Nomos X: REPRESENTATION, supra note 96, at 167, 184-85 (presenting the three different methods used by the Court to measure malapportionment in the 1964 reapportionment cases).

102 See Wesberry, 376 U.S. at 18.

103 Reynolds, 377 U.S. at 577.

104 See id. at 578-81; see also Mahan v. Howell, 410 U.S. 315, 322 (1973) (finding the equal protection standard for state legislative redistricting less strict than the article I, section 2 standard governing congressional redistricting). Compare Karcher v. Daggett, 462 U.S. 725 (1983) (invalidating New Jersey legislative plan with variance of $0.6984 \%$ between largest and smallest congressional districts) with Brown v. Thomson, 462 U.S. 835 (1983) (sustaining Wyoming state legislative plan with a population variance of $89 \%$ between largest and smallest districts, which resulted from the statutory entitlement of each county to its own representative, because legitimate state policy of preserving integrity of political subdivision was applied in a consistent and nondiscriminatory fashion and dilution of voting power on which challenge was based was de minimus). Other commentators have discussed this inconsistency. See Grofman, supra note 93, at 82-83 (reviewing, inter alia, Karcher and Brown, both decided the same day, and the Burger Court approach to the state-congressional dichotomy in redistricting); Lowenstein \& Steinberg, The Quest for Legislative Districting in the Public Interest: Elusive or Illusory?, 33 UCLA L. REv. 1, 16-17 (1985) (same-adding that the result in Karcher is preferable to that in Brown); Sherry, Civic Virtue and the Feminine Voice in Constitutional Adjudication, 72 VA. L. REv. 493, 596-98 (1986) (noting that Justices Burger, Rehnquist, and Powell upheld both plans; that Justices Brennan, Marshall, and Blackmun struck down both; and arguing that Justice White's vote to sustain the plan in Karcher but not that in Thompson was motivated by the degree of malapportionment; that Justice Stevens distinguished the cases based on political gerrymandering; and that Justice O'Connor's opinion is explainable in terms of republicanism). See generally Dexter, Standards for Representative Selection and Apportionment, in Nomos X: RePRESENTATION, supra note 96, at 158-66 (decrying the overemphasis of "one man, one vote" and the underemphasis of communication areas, cultural and social groups, interests, traditions, legislative efficiency and efficacy, and social invention); Dixon, supra note 1, at 220 (The absolute population equality rule for congressional redistricting "leaves little or no room for recognition of traditional political subdivision lines[,] ... may reduce creativity ... [, and] foster gerrymandering.").

${ }_{105}$ The Court sought to guarantee the latter. See Reymolds, 377 U.S. at 579 ("Whatever the means of accomplishment, the overriding objective must be substantial equality of population among various districts, so that the vote of any citizen is approx- 
of the individual to combine her vote with others. ${ }^{108}$ As Justice Stewart noted in dissent in Lucas v. Forty-Fourth General Assembly, ${ }^{107}$ the companion case to Reynolds, equally populated districts do not necessarily guarantee majoritarian rule. ${ }^{108}$ For example, by using political gerrymandering, a numerically inferior but politically dominant party can create equally populated districts yet waste votes of the subordinate political party by packing the latter's votes in a few districts. ${ }^{100}$ Votes are wasted in any election, however, even without gerrymandering. ${ }^{110}$ The only alternatives that better ${ }^{111}$ recognize an equally effective vote are

imately equal in weight to that of any other citizen in the State." (emphasis added)). The distinction is significant. See Rogowski, supra note 35, at 426-30 (presenting four competing doctrines of the right to representation and their consequences: no right to representation, the right to representation, the right to fair representation, and the right to equally powerful representation); Still, supra note 92 , at 378-85 (presenting six criteria for political equality: universal equal suffrage, equal shares of the total vote in a political unit, equal probabilities of casting the deciding vote, anonymity, majority rule, and proportional group representation). See generally Grofman, Fair and Equal Representation, 91 ETHICs 477, 477-83 (1981) (discussing problems posed by the Rogowski and Still analyses); Rae, Two Contradictory Ideas of (Political) Equality, 91 ETHICs 451, 451-54 (1981) (distinguishing between "treating different people differently in order to threat them equally" and treating people "identically in order to treat them equally").

${ }_{108}$ See Note, The Constitutional Imperative of Proportional Representation, 94 YALE L.J. 163, 177-82 (1984) (examining the tension in Reynolds between individual and group rights). But see Lowenstein, supra note 5 , at 6 (arguing that the rights vindicated in Reynolds are those of the individual, not the group; the restructuring of the electoral system resulting from that vindication was a by-product, not a constitutional end).

107377 U.S. 713 (1964); see also Blacksher \& Menefee, supra note 74, at 13 \& n.93 (discussing, among other things, Jưstice Stewart's dissent in Lucas). A congressional attempt to amend the Constitution to reverse Lucas, the so-called "Dirksen Amendment," failed. See 111 CoNG. REC. 19,373 (1965); see also Backstrom, Robins \& Eller, supra note 1, at 1125 n.18 (noting the failure of the Dirksen Amendment). ${ }^{108}$ See Lucas, 377 U.S. at 750 n.12 (1964) (Stewart, J., dissenting); see also Baker, Neutrality, Process, and Rationality: Flawed Interpretations of Equal Protection, 58 TEx. L. Rf.v. 1029, 1074 (1980) (demonstrating by example how equally populated districts and minority rule may not be inconsistent); Lowenstein \& Steinberg, supra note 104, at 6-7 (same (citing Bernoulli's theorem)); Note, supra note 106, at $166 \mathrm{n} .13$ (stating that a minority of "the voters can elect a majority of the legislators"). But see Lowenstein, supra note 5, at 7 (arguing that Justice Stewart's focus on the number of voters who could elect a majority of the legislature because the right to vote is an individual right, not a right of $26 \%$ or $74 \%$ ).

One commentator has taken a different tack and argued that Lucas was wrongly decided because the Reynolds Court misinterpreted the guarantee clause. See Note, Rule of Law, supra note 37, at 576-77.

109 See Davis, 106 S. Ct. at 2802 n.6; Backstrom, Robins \& Eller, supra note 1, app. at 1154; Grofman, supra note 93, at 117.

110 See Levinson, supra note 93, at 265 (noting that those who vote for losers in any election are by definition underrepresented, as their votes are discarded); Lowenstein \& Steinberg, supra note 104, at 14 n.36 (same).

111 The word "better" is deliberately used to address the criticism that even under proportional representation, some votes are wasted in any system in which representation is discrete and finite. See supra note 110. 
proportional representation or "at-large election of every representative body at every level."112 But the at-large election can be an unconstitutional device to discriminate against minorities. ${ }^{113}$ For example, if blacks comprise only one-third of the voters in a multimember district, a black can never hold office without white support, while a white can win without black support even when blacks are concentrated in one part of the multimember district. ${ }^{114}$ Thus, the only remaining remedy is proportional representation. ${ }^{115}$ The Davis Court unanimously

112 Rogowski, supra note 36 , at 429 . Actually, at-large representation via multimember districts is the rule, not the exception, in a majority of local jurisdictions, for positions on city, county and school district boards. See Baker, supra note 44, at 274; see also L. TRIBE, AmErican Constrtutional LAw § 13-8 (1978) (describing legal challenges to multimember districts and the constitutional standards by which multimember districts have been evaluated); Carpeneti, supra note 32, at $670 \mathrm{nn} .23-24$ (defining and describing "multimember district" in which "at-large elections" are held as opposed to single member districts); Copeland, supra note 86, at 424 (same). In the case of state legislatures, 30 of 99 state legislative chambers were based at least in part on multimember districts in 1981. See Grofman, supra note 93, at 177-80. In the case of congressional districts, statute prohibits the use of multimember districts except in states that have "in all previous elections elected its Representatives at large . . ." 2 U.S.C. $\& 2 c$ (1982).

113 See Rogers v. Lodge, 458 U.S. 613, 616-17 (1982); City of Mobile, 446 U.S. at 105 (Marshall, J., dissenting); White v. Regester, 412 U.S. 755, 765 (1973); see also Baker, supra note 44, at 268 ("The second problem of multimember districts is the impact of winner-take-all elections on minority groupings in a particular district."); Blacksher \& Menefee, supra note 74, at 37 \& n.255 (criticizing the turn-of-the-century progressive movement with its advocacy of at-large districting as aiming to "put in office the "best' citizens from all-white business and professional classes" while "neutralizing readily mobilized racial, ethnic and economic minority groups"); Copeland, supra note 86 , at 424 (noting the argument that racially polarized voting and multimember districting leads to minority vote dilution); Engstrom \& McDonald, supra note 75 , at 204 (describing the argument that at-large election schemes discriminate against racial minorities); Note Ghetto Voting and At-Large Elections: A Subtle Infringement upon Minority Rights, 58 GEo. L.J. 989, 996-97 (1970) (arguing that at-large systems in contrast to wards discriminate against blacks). See generally Grofman, Alternatives to Single-Member Plurality Districts: Legal and Empirical Issues, in REPRESENTATION AND REDISTRICTING Issues, supra note 84, at 107, 112-17 (concluding, in light of nine studies of multimember jurisdictions, that multimember districts discriminate against minorities more than single-member districts).

114 See Butler, Constitutional and Statutory Challenges to Election Structures: Dilution and the Value of the Right to Vote, 42 LA. L. REv. 851, 868 (1982) ("Because blacks are not a majority of the voting age population in many American cities, when elections are conducted at-large a black candidate must receive white support to be elected.").

115 Proportional representation is not without certain advantages. See Hallett, Proportional Representation with the Single Transferable Vote: A Basic Requirement for Legislative Elections, in Choosing AN ElECTORAL. SySTEM: Issues AND ALTERNATIVES 113, 117-24 (A. Lijphart \& B. Grofman eds. 1984) [hereinafter CHoosing an Electoral System]; Lakeman, The Case for Proportional Representation, in id. at 41,44-51; Note, supra note 106, at 182-88. But see Duverger, Which Is the Best Electoral System?, in Choosing AN Electoral SySTEM, supra, at 38-39 (arguing that plurality and majority systems are preferable to proportional representation in certain circumstances); Hermens, Representation and Proportional Representation, in id. 
agreed, however, that the Constitution does not mandate proportional representation. ${ }^{116}$

\section{Political Gerrymandering}

The "equally effective" vote language in Reynolds ${ }^{117}$ inevitably created a tension between majoritarian rule and proportional representation. ${ }^{118}$ Nonetheless, the Court refused to consider the justiciability of political gerrymandering in a series of summary dispositions. ${ }^{119}$ The first indication that the Court might hold political gerrymandering justiciable was Gaffney v. Cummings. ${ }^{120}$ The Gaffney Court upheld a Connecticut reapportionment scheme in which a board, appointed by representatives of both political parties, ${ }^{121}$ adhered to a "policy of 'political fairness." "122 Under this policy, the board proposed to adopt a plan structured to reflect in both houses of the state legislature the two parties' political strength. ${ }^{\mathbf{1 2 3}}$ This policy amounted to a "bipartisan ger-

at $15,19-23$ (describing the political fragmentation caused by proportional representation).

${ }_{118}$ See Davis, 106 S. Ct. at 2809; id. at 2817, 2823-24 (O'Connor, J., concurring in the judgment); id. at $2830 \mathrm{n} .7$ (Powell, J., concurring and dissenting).

117377 U.S. at 565, 581 ("effective and adequately weighted vote").

118 Professor C. Edwin Baker states that "[t]he notion of equal efficacy of votes has no apparent operational meaning in the districting context" because the consequences to the individual voter of redistricting depend on her values, and voters' values differ. Baker, supra note 108, at 1078. If that is true, however, then a gerrymander cannot, by definition, exist. What matters for equal protection purposes is not how voters view their own values but the objective purpose of those doing the redistricting. See id. at 1079-80 (the "equality of respect" explanation).

119 See, e.g., Jimenez v. Hidalgo County Water Improvement Dist. No. 2, 424 U.S. 950 (1976), affg 68 F.R.D. 668 (S.D. Tex. 1975) (refusing, inter alia, to expand constitutional protection from political gerrymandering when no racial discrimination is involved); Ferrell v. Hall, 406 U.S. 939 (1972), aff'g Ferrell v. Oklahoma ex rel. Hall, 339 F. Supp. 73 (W.D. Okla. 1972) (holding that political gerrymandering in singlemember districting is nonjusticiable (citing Wells v. Rockefeller, 398 U.S. 901 (1970); WMCA, Inc. v. Lomenzo, 382 U.S. 4 (1965))); Wells v. Rockefeller, 398 U.S. 901 (1970), aff'g 311 F. Supp. 48 (S.D.N.Y. 1970) (holding that political gerrymandering is nonjusticiable as long as redistricting plan complies with the Reynolds mandate of equal representation); WMCA, Inc. v. Lomenzo, 382 U.S. 4, 5-6 (1965) (Harlan, J., concurring) (explicitly rejecting the argument that political gerrymandering may be subject to federal consitutional attack).

120412 U.S. 735 (1973).

121 Id. at 736 .

122 Id. at 738.

${ }^{123}$ Id. By maximizing the number of safe seats, both parties conversely minimized the number of competitive or swing seats. Commentators have criticized the diminishment of swing seats as fostering "increased rigidity in decisionmaking and insensitivity to changing public opinion on the part of seemingly unbeatable legislators." Backstrom, Robins \& Eller, supra note 1, at 1130 n.31 (citing Erikson, Malapportionment, Gerrymandering, and Party Fortunes in Congressional Elections, 66 AM. Pol. SCI. Rev. 1234 (1972); Lebedoff, The Essential Reform, HARPERS, Oct. 1976, at 16-19; Mayhew, Congressional Representation: Theory and Practice in Drawing the Districts, in 
rymander:"124 "I'll scratch your back if you'll scratch mine." But in sustaining the plan, the Gaffney Court recognized the inherent context of the redistricting process: "Politics and political considerations are inseparable from districting and apportionment." ${ }^{25}$ The Court flatly rejected suggestions ${ }^{126}$ that those who redistrict should ignore political data because such an approach might produce "the most grossly gerrymandered results."127

The tension in Reynolds manifests itself in Gaffney. Read narrowly, Gaffney stands not only for the proposition that political gerrymandering is justiciable but also for the proposition that "whatever harms political gerrymandering may sometimes occasion should be tolerated as inextricably associated with the legislative business of redistricting." ${ }^{128}$ In other words, the majority's decisions prevail. ${ }^{129}$ If read in light of a broad interpretation of the Reynolds "equally effective

REAPPORTIONMENT IN THE 1970s 249 (N. Polsby ed. 1971); Tufte, The Relationship Between Seats and Votes in Two-Party Systems, 67 AM. Pol. ScI. Rev. 540, 549-53 (1973)); see also Comment, Political Gerrymandering: A Statutory Compactness Standard as an Antidote for Judicial Impotence, 41 U. CHI. L. REv. 398, 401 (1974) (maintaining that "legislatures should be apportioned so as to minimize the extent to which any representative is able to rely solely on a single interest group"). But see infra note 319 and accompanying text (noting the values of stability and experience in legislator-constituent relations).

${ }^{124}$ See Davis, $106 \mathrm{~S}$. Ct. at 2821-22 (O'Connor, J., concurring in the judgment) (citing Gaffney as a constitutionally permissible bipartisan gerrymander).

${ }^{125}$ Gaffney, 412 U.S. at 753.

${ }^{128}$ See, e.g., Congressional Anti-Gerrymandering Act of 1979: Hearings on S. 596 Before the Senate Comm. on Governmental Affairs, 96th Cong., 1st Sess. 37 (1979) (statement of David Cohen, President, Common Cause) (testifying as to the distortions that have resulted in the past from politically influenced redistricting plans); B. CAIN, supra note 84 , at $2-4$ (outlining proposals to reform redistricting and commenting on the danger of treating redistricting as a political question); CoMmON Cause, Toward a System of Fair and Effective Representation 40-79 (1977) (offering a model state constitutional amendment and act prohibiting the use of political data in redistricting); Adams, $A$ Model State Reapportionment Process: The Continuing Quest for "Fair and Effective Representation," 14 HARV. J. ON LEGIS. 825, 864904 (1977) (offering a model state constitutional amendment and act prohibiting the use of political data in redistricting). It is beyond the scope of this Comment to discuss the appropriateneśs of redistricting by "nonpartisan" commissions. But see B. CAIN, supra note 84, at 189 ("[T]he public should protect its own interests . . ."); J. Locke, Of Civil. Government, Second Treatise $\S 141$ (Gateway Editions, Ltd. ed. 1955) (1689) ("The legislative cannot transfer the power of making laws to any other hands; for it being but a delegated power from the people, they who have it cannot pass it over to others."); Dixon, supra note 1, at 245 ("Nonpartisan politics is a contradiction in terms."); Grofman, supra note 93, at 124 (redistricting "involves the need to reconcile multiple and conflicting desirable social goals").

${ }^{127}$ Gaffney, 412 U.S. at 753, quoted in Davis, 106 S. C.t. at 2808.

128 Davis, 106 S. Ct. at 2821 (O'Connor, J., concurring in the judgment).

129 But of. Lucas v. Forty-Fourth Gen. Assembly, 377 U.S. 713, 736-37 (1964) (overturning Colorado reapportionment plan approved by statewide referendum). 
voice,"130 however, Gaffney would intimate that proportional representation is constitutionally mandated. ${ }^{\mathbf{1 3 1}}$

A more recent decision that propelled the Court towards its holding in Davis was Karcher v. Daggett. ${ }^{132}$ In Karcher, the Court invalidated, on "one person, one-vote" grounds, a New Jersey congressional redistricting plan in which the variance in population from the largest to the smallest district was $0.6984 \% .{ }^{133}$ The Karcher Court rejected the defense that the variance was de minimis. "If we accept that argument, how are we to regard deviations of $0.8 \%, 0.95 \%, 1 \%$, or $1.1 \%$ ?" asked Justice Brennan. ${ }^{134}$ Justice Stevens, concurring, asserted that the New Jersey plan was also political gerrymandering. Justice Stevens argued that racial and political gerrymandering were indistinguishable since the same equal protection clause applied to both; ${ }^{135}$ he then presented criteria that a plaintiff must show in order to establish a prima facie case of political gerrymandering. ${ }^{136}$ If a plaintiff met those criteria, Justice Stevens would then shift the burden to the state to defend the plan. ${ }^{137}$ Justice White dissented from Justice Brennan's majority, calling the mathematical inequality "a trifling."138 Justice White noted, however, that "a far greater potential threat to equality of representation [was] the gerrymander."139 Finally, Justice Powell dissented but

130 Reynolds, 377 U.S. at 565.

131 See Gaffney, 412 U.S. at 752-53; cf. Casper, Apportionment and the Right to Vote: Standards of Judicial Scrutiny, 1973 SuP. CT. REv. 1, 23 (arguing that in Gaffney the Court permitted proportional representation but did not mandate it); Note, supra note 106, at 169 \& n.35 (noting that in Gaffney the Court specifically approved a proportional representation plan).

132462 U.S. 725 (1983); see also Note, supra note 106, at 170 n.37 (analyzing each Justice's opinion in terms of the problems of gerrymandering).

${ }^{133}$ See Karcher, 462 U.S. at 728, 740-42; see also Weinstein, Partisan Gerrymandering: The Next Hurdle in the Political Thicket?, 1 J.L. \& PoL. 357, 360-62 (1983) (summarizing the Karcher litigation).

${ }^{234}$ Karcher, 462 U.S. at 732.

1so See id. at 749-50 (Stevens, J., concurring); see also Cousins I, 466 F.2d at 850 ("[T]he Equal Protection Clause protects 'voting rights and political groups ... . as well as economic units, racial communities, and other entities." " (quoting Williams v. Rhodes, 393 U.S. 23, 39 (1968) (Douglas, J., concurring))); Weinstein, supra note 133 , at 363 ("Justice Stevens had no doubt that equal protection principles apply to partisan gerrymanders.").

${ }^{136}$ See Karcher, 462 U.S. at 750-61 (Stevens, J., concurring).

${ }^{137}$ Id. at 760-61 (Stevens, J., concurring).

138 See id. at 766 (White, J., dissenting).

138 Id. at 776 (White, J., dissenting) (quoting Wells v. Rockefeller, 394 U.S. 542, 555 (1969) (White, J., dissenting)). Since Karcher precludes discrepancies in population among districts in congressional seats and requires meaningful justification in state legislative redistricting, gerrymandering "is the main tool available to legislatures that seek to use the redistricting process to advantage one political group over another." Weinstein, supra note 133, at 358; see also Baker, supra note 44, at 270-71 (concluding that the gerrymanders of 1970 and 1980 were more elaborate than previous years because of the need to construct districts of equal population). See generally P. Mus- 
expressed his concern that gerrymandering is "profoundly destructive of the apportionment goal of 'fair and effective representation." "140

\section{Davis v. Bandemer: The Decision}

Six members of the Davis Court took the next logical step from the "equally effective vote" language in Reynolds $v$. Sims $s^{\mathbf{1 4 1}}$ and held that redistricting presented a justiciable question. A constitutional requirement of proportional representation, the logical endpoint of this progression, is not, however, consistent with pluralism and republicanism. ${ }^{142}$ Thus the six Justices split into two camps, one led by Justice White, the other by Justice Powell, as how best to employ equal protection standards in an attempt to brake the slide towards proportional representation. Part A of this section analyzes the justiciability holding and demonstrates that both Justice White's majority opinion and Justice O'Connor's dissent are consistent with constitutional theories of republicanism and pluralism; their disagreement is merely one of degree, not of kind. Part B then looks at the competing equal protection standards that Justices White and Powell present.

\section{A. Justiciability}

Taking the next logical step from the "equally effective" language in Reynolds, six members of the Court in Davis held that redistricting presented a justiciable question. Justice White began his opinion for the majority by summarizing the Court's expansion of judicial review from Baker to Reynolds, the racial gerrymandering cases, and the bipartisan political gerrymandering case, Gaffney. ${ }^{\mathbf{1 4 3}}$ Justice White then dismissed the post-Baker summary treatments of political gerrymandering cases as not controlling. ${ }^{144}$ Justice White reviewed the political question doctrine enunciated in Baker and held that it did not bar adjudication of Bandemer's claim. ${ }^{145}$ In particular, Justice White rejected the argument that the inability to develop a clear standard precluded

GROVE, supra note 6 , at 51-52 (collecting literature on the impact of the requirement of mathematical equality on political gerrymandering).

${ }^{140}$ Karcher, 462 U.S. at 787 (Powell, J., dissenting).

141377 U.S. 533, 565 (1964).

142 Yet another objection beyond the scope of this Comment is that proportional representation cannot result from plurality-based districts. See Grofman, supra note 93, at 158-59 ("This statistical fact cannot be changed by court fiat.").

${ }^{143}$ See Davis, 106 S. C. at 2803-04.

144 Id. at 2804.

${ }^{145}$ See id. at 2804-06. 
justiciability. ${ }^{140}$

Three members of the Court disagreed. Justice O'Connor, writing for Chief Justice Burger, Justice Rehnquist, and herself, strongly maintained that the majority's decision was inconsistent with the emergence of a stable two-party system and the Framers' intent. ${ }^{147}$ First, the Court's equation of racial and political minorities was both erroneous $^{148}$ and an invitation to the members of every identifiable group to bring gerrymandering claims. ${ }^{149}$ Second, the Framers never contemplated any group right to representation. ${ }^{150}$ Third, numerical gerrymandering was distinguishable from political gerrymandering because no bright lines such as one person, one vote exist in the political context. ${ }^{151}$ Finally, the majority's reliance on Gaffney was misplaced; in Gaffney the Court had sustained the political gerrymandering. ${ }^{162}$

In terms of constitutional theory, however, the disagreement between the wings of the Court appears to be more a matter of degree than of kind. Both the opinions of White and O'Connor are consistent with a model of "deliberative democracy" which combines elements of pluralism and republicanism. . $^{153}$ Pluralism treats "the political system as, ideally, designed to serve the self-defined private interests of individuals or groups, fairly represented in political forums, where they compete under fair rules for fair shares of the outputs of public policy."154

146 See id. at 2805.

${ }^{147}$ See id. at 2817 (O'Connor, J., concurring in the judgment).

148 See id. at 2819-21 (O'Connor, J., concurring in the judgment).

149 See id. at 2818 (O'Connor, J., concurring in the judgment); $c f$. supra note 8 (noting the response to Davis).

${ }_{160}$ See Davis, 106 S. Ct. at 2818 (O'Connor, J., concurring in the judgment); $c f$. Baker v. Carr, 369 U.S. 186, 301 (1962) (Frankfurter, J., dissenting) (arguing that the Framers never contemplated the justiciability of malapportionment claims).

151 See Davis, $106 \mathrm{~S}$. Ct. at 2818 (O'Connor, J., concurring in the judgment).

152 See id. at 2821-22 (O'Connor, J., concurring in the judgment).

103 See Sunstein, Interest Groups in American Public Law, 38 Stan. L. Rev. 29, $45-49$ (1985); see also J. MANSBRIDGe, Beyond Adversary Democracy 293-98 (1983) (describing the interplay between adversarial relations and the unifying tendencies of civic virtue in politics at the national level); Mansbridge, Living with Conflict: Representation in the Theory of Adversary Democracy, 92 ETHICs 466, 469 (1981) (noting that representation can combine unitary (republican) and adversary (pluralist) forms); $c f$. Michelman, The Supreme Court, 1985 Term-Foreword: Traces of SelfGovernment, 100 HARv. L. REv. 4, 58-60 (1986) (criticizing Sunstein for consigning civic virtue to elected representatives and pluralism to the citizenry).

${ }^{154}$ Michelman, supra note 153 , at 21 ; see also J. ELY, supra note 37 , at 80 (defining pluralism as structuring government "so that a variety of voices would be guaranteed their say and no majority coalition could dominate"); Ackerman, Beyond Carolene Products, 98 HARv. L. REv. 713, 720 (1985) (describing pluralist politics as "myriad pressure groups, each typically representing a fraction of the population, bargain[ing] with one another for mutual support"); Bennett, Reflections on the Role of Motivation under the Equal Protection Clause, 79 Nw. U.L. Rev. 1009, 1012 (1984) (noting that from the pluralist perspective, trade-offs reconcile and advance the private 
Madison's statement in The Federalist Papers is a classic example of pluralism: "Whilst all authority in it will be derived from and dependent on the society, the society itself will be broken into so many parts, interests, and classes of citizens, that the rights of individuals, or of the minority, will be in little danger from interested combinations of the majority."1ss

In other words, society is composed of atomistic individuals, each of whom has a different set of multifaceted preferences. ${ }^{156}$ The diversity of preferences varies directly with the size of the society. ${ }^{157}$ As the society expands, factions, the bane of society, ${ }^{158}$ are subsumed. ${ }^{159}$ Moreover, the loser of one battle is likely to be the winner of another. ${ }^{160}$ Hence politics is a series of ever changing coalitions, each varying with the issue.

The alternative conception that framed early discussion of the Gonstitution is republicanism. Republicanism is predicated on civic virtue, or the ability of citizens to set aside private interests in pursuit of

interests of organized groups); Sunstein, supra note 153, at 33-34 (describing various relations among pluralist factions).

183 The Federalist No. 51, at 358 (J. Madison) (B. Wright ed. 1961); see also The Federalist No. 39, at 281 (J. Madison) (B. Wright ed. 1961) ("It is essential to such a government that it be derived from the great body of the society, not from an inconsiderable proportion, or a favored class of it.").

${ }^{166}$ See Bennett, supra note 154, at 1022 ("No person has a single political identity."); see also The FEDERAlist No. 10, at 131 (J. Madison) (B. Wright ed. 1961) ("A zeal for different opinions concerning religion, concerning government, and many other points" is part of the nature of mankind ....").

${ }_{182}$ As Madison wrote: "The smaller the society, the fewer probably will be the distinct parties and interests composing it . . . Extend the sphere, and you take in a greater variety of parties and interests." ThE FEDERALIST No. 10, supra note 156, at 135.

258 See id. at 129 ("[t]he instability, injustice, and confusion introduced into the public councils [by factions], have, in truth, been the mortal diseases under which popular governments have everywhere perished").

159 Compare The Federalist No. 51, supra note 155, at 358 (in "more circumscribed Confederacies, or States, oppressive combinations of a majority will be facilitated") with id. at 359 ("In the extended republic of the United States, and among the great variety of interests, parties, and sects which it embraces, a coalition of a majority of the whole society could seldom take place on any principles other than those of justice and the general good . . . ."). Madison maintained that the preferred method for government to protect minority factions was "by comprehending in the society so many separate descriptions of citizens as will render an unjust combination of a majority of the whole very improbable, if not impracticable." Id. at 358; see also Hermens, supra note 115 , at 17 (recounting the success of Madison's theory of government).

${ }_{160}$ See Bennett, supra note 154, at 1022 ("As the field of governmental activity has expanded, so has the likelihood that victims of factional politics on one issue will be beneficiaries on another."). But cf. Grofman, For Single-Member Districts Random is Not Equal, in REPRESENTATION AND REDISTRICTING Issues, supra note 84, at 55 (recognizing that in a winner-take-all, first-past-the-post majoritarian system of government, minorities are underrepresented). 
the commonweal. ${ }^{161}$ As Hamilton wrote in The Federalist Papers:

When occasions present themselves, in which the interests of people are at variance with their inclinations, it is the duty of the person whom they have appointed to be the guardians of those interests, to withstand the temporary delusion, in order to give them time and opportunity for more cool and sedate reflection. ${ }^{\mathbf{1 6 2}}$

Unlike pluralism, wherein preferences are exogenous to the political process, republicanism makes preferences endogenous. ${ }^{163}$ Political participation is not relegated to the casting of ballots in the marketplace of interests; rather it is highly deliberative. ${ }^{104}$ Moreover, unlike pluralism, which relies on the market to prevent the tyranny of faction, education and prevailing morality are the principal defenses of republicanism. ${ }^{165}$ Whereas pluralism links the expansion of society to the reduced capac-

161 See J. Rousseau, The Social Contract 19-22 (R. Harrington trans. 1893). Rousseau indicates that the perfect social compact involves:

the total alienation of each associate with all his rights to the entire community ....

... [T] as it can be, and no associate has anything to claim: for, if some rights remained to individuals . . . each being in some points his own judge, would soon profess to be so in everything; . . . the association would necessarily become tyrannical and useless.

Id. at 21; see also Michelman, supra note 153, at 18 ("Republicanism's 'animating principle' is said to be civic virtue."); $i d$. at 58 ("Civic virtue can be understood as a certain combination of motivation and ability: the motivation to deal with public questions by sincere engagement in deliberative colloquy aimed at discernment of the general good, and the ability to do it well.").

${ }_{162}$ The Fedfralist No. 71, at 459 (A. Hamilton) (B. Wright ed. 1961).

163 See Sunstein, supra note 153, at 31; Sunstein, Naked Preferences and the Constitution, 84 Colum. L. REv. 1689, 1691 (1984).

164 See J. RousSEAU, supra note 161, at 158 ("As long as men united together look upon themselves as a single body, they have but one will relating to the common preservation and general welfare."); see also Michelman, supra note 153, at 19 (" $[R]$ epublicanism favors a highly participatory form of politics, involving citizens directly in dialogue and discussion"); Sunstein, supra note 153, at 31 ("through discussion people can . . . escape private interests and engage in pursuit of the public good"). See generally G. Stone, L. Seidman, C. Sunstein \& M. Tushnet, ConstituTIONAL. LAW 5-7 (1986) [hereinafter Constitutional LAw] (summarizing the argument underlying republicanism).

${ }_{185}$ See J. Rousseau, supra note 161, at 57 ("the public must be taught to know what it wants"); id. at 59 ("He who ventures to undertake to give institutions to a people, should feel himself in [a] condition to . . . transform the individual"); $i d$. at 65 ("the wise lawgiver will not begin by making good laws, but he will first see whether the people for whom they are destined is [sic] ready to bear them."); Sunstein, supra note 153, at 32 ("instill principles of virtue in the hope of ensuring that the spirit of faction will not develop"); see also Michelman, supra note 153, at 18-19 ("Cultivation of this public spirit is 'government's first task" (citing ConstrTutional LAw, supra note 164 , at 5$)$ ). 
ity of factions to combine against the public interest, republicanism minimizes the size of society in order to maximize civic virtue. ${ }^{166}$

Professor Sunstein has developed a spectrum he labels "deliberative democracy," which reconciles the differences between these competing constitutional theories. ${ }^{\mathbf{1 6 7}}$ At the republican extreme lies a Congress that deliberates important issues in the interest of society as a whole. ${ }^{\mathbf{1 6 8}}$ At the other end, the pluralist extreme likens congressional lawmaking to the operation of a marketplace. ${ }^{169}$ Although Professor Sunstein declines to suggest where any particular issue falls along this spectrum, ${ }^{\mathbf{1 7 0}}$ his model provides an informative framework for analyzing the White

${ }^{168}$ See J. Rousseau, supra note 161, at 68-72. As Rousseau observed:

Nature has fixed a limit to the stature of a well-formed man, and when this limit is passed there are only giants and dwarfs; it is the same with regard to the best constitution of a state. . . . There is in every political body a maximum of force which it cannot pass, and from which it often recedes after having enlarged itself too much. The farther the social cord is stretched, the more relaxed it becomes; and in general a small state is proportionately stronger than a large one.

Id. at $68-69$; $c f$. Michelman, supra note 153, at 19 (An expanded national sphere "would lack the spiritual and material homogeneity . . required to support and reward unselfish devotion to the common good" and would deprive citizens of the "deliberation and debate which 'inculcate[s] civic virtue." (citing Constitutional Law, supra note 164 , at 5)).

Of course, Rousseau qualified his argument regarding size by recognizing the state's need to protect itself:

On the other hand the state should give itself a certain basis for the sake of solidity, to resist the shocks which it will not fail to experience . . . . The weak risk being soon swallowed up; and none can be preserved except by placing themselves in equilibrium with the others, which equalizes the pressure.

J. Rousseau, supra note 161 , at 71 .

The ideal model of republicanism is the town meeting. Sunstein, supra note 153, at 31; see also J. MANSBRIDGE, supra note 153, at 39-138 (using a town meeting as a paradigm for studying the relationship between adversary (pluralist) and unitary (republican) politics). As to the apportionment that may be necessary in larger groups, Rousseau viewed it as a necessary evil. "People the territory equally, extend everywhere the same rights, carry everywhere abundance and life . . . Remember that the walls of cities are formed from the ruins of country dwellings. For each palace that I see erected in the capital, I seem to see a whole country in ruins." J. RousSEAU, supra note 161, at 141; see also de Grazia, General Theory of Apportionment, 17 LAw \& Contemp. Probs. 256, 256 (1952) (citing Rousseau's view that apportionment is a necessary evil).

${ }_{187}$ See Sunstein, supra note 153, at 45-48; see also Lucas, supra note 46, at 766 (noting the representative and deliberative nature of assemblies); Pennock, Political Representation: An Overview, in Nomos X: RePRESENTATION, supra note 96 , at 1421 (discussing the distinction between representation by "delegates" and by "trustees," the latter having greater discretion to make choices in the interest of their constituency); cf. Michelman, supra note 153, at 55 (analyzing Sunstein's model).

168 See Sunstein, supra note 153 , at 45-48.

189 See id.

170 See id. 
and O'Connor opinions in Davis v. Bandemer. ${ }^{171}$

Justice White's view that political gerrymandering is justiciable falls closer to the pluralist pole. One explanation of Justice White's position is that groups that are victimized by political gerrymandering are excluded from the political process; the Court is merely intervening to mitigate exclusion, that is, to rectify this political market failure. ${ }^{172}$ A second explanation places the right to an equally effective vote within a "shield of 'rights'-spheres of individual autonomy into which government [via political gerrymandering] may not enter."173 A third, more persuasive rationale precludes redistricting with the purpose of disparaging any person or group. ${ }^{174}$ Each rationale places Justice White at the pluralist end of Sunstein's spectrum.

Placing Justice O'Connor's opinion on the spectrum is more problematic. One interpretation, consistent with her complaint that Justice White provides no manageable standards, ${ }^{175}$ is that "[p]olitics consists of uninhibited interest-group struggle in the expectation that the struggle will promote social welfare better than any alternative system."176 This nears the pluralist pole; political gerrymandering is merely the legislative market at work. Other language in Justice O'Connor's opinion, however, suggests a more republican interpretation of political gerrymandering. ${ }^{177}$ For example, she argued that "the opportunity to con-

171106 S. Ct. 2797 (1986).

172 See id. at 2803; see also Ackerman, supra note 154, at $715 \mathrm{n} .4$ (arguing that the Court's concern should be about the capacity of a group to effectuate substantive political outcomes); Sunstein, supra note 153, at 34 (discussing the conception of minority groups articulated by the Court in United States v. Carolene Prods. Co., 304 U.S. 144, 152 n.4 (1938)); $c f$. Karst, supra note 8, at 347 (discussing continuing problems in the dilution of minority votes); Note, Rule of Law, supra note 37, at 574 ("Certain factions within the states had gained and maintained a stranglehold on state governments by effectively excluding other factions from equal participation in state politics ...." (footnote omitted)).

173 Sunstein, supra note 153 , at 33.

174 See Baker, supra note 108, at 1079; Baker, Outcome Equality or Equality of Respect: The Substantive Content of Equal Protection, 131 U. PA. L. REv. 933, 97284 (1983); cf. Neal, supra note 50, at 274 (injury in numerical gerrymandering cases is to a group (e.g. urban versus suburban interests), whereas injury in racial gerrymandering is a personal injustice).

${ }_{178}$ See Davis, $106 \mathrm{~S}$. Ct. at 2822 (O'Connor, J., concurring in the judgment).

178 Sunstein, supra note 153 , at 33 .

177 In the numerical gerrymandering case, Brown v. Thomson, 462 U.S. 835 (1983), Justice O'Connor provided the key vote in sustaining a Wyoming redistricting plan that guaranteed a representative for every county but allowed an $89 \%$ deviation from population equality. Id. at 848 (O'Connor, J., concurring in the judgment). On the same day the Court decided Brown, however, Justice O'Connor provided a key vote in Karcher v. Daggett, 462 U.S. 725 (1983). Professor Sherry argues that:

Both votes are consistent with classical republican ideals. In Karcher, O'Connor voted to uphold the principle of "one person, one vote," thus preserving to each citizen an undiluted voice in the electoral process. In 
trol the drawing of electoral boundaries ... plays no small role in fostering active participation in the political parties at every level."178 Redistricting is thus a means to a consensually agreed upon end of encouraging political participation. ${ }^{179}$ The more this end is the product of

\begin{abstract}
Brown, however, that republican principle coilided with another classical ideal. O'Connor's reliance on the importance of preserving county boundaries, a justification rejected by the liberal dissenters, echoes a theme . . . : the notion of the community itself as an independent entity with interests to be protected. O'Connor was willing to protect individuals' access to community membership and participation only to the point at which it conflicted with ensuring the viability of a certain type of community. The priority of the community's interests, at the cost of diminishing the value of membership for some of its members, recalls the republican demand that individuals subordinate their selfish desires for the needs of the collective. O'Connor's emphasis on the fact that the additional deviation in this case was quite small suggests both a limit to the sacrifices that communities may demand of their members and a feminine tendency to examine apportionment questions in context rather than in the abstract.
\end{abstract}

Sherry, supra note 104, at 598 (footnotes omitted).

${ }_{178}$ Davis, 106 S. C. at 2817; see also Bickel, The Durability of Colegrove v. Green, 72 YALE. L.J. 39, 42-43 (1962) (offering an example of gerrymandering fostering political parties in which the governor and a majority of voters are of one party but the state legislature is controlled by the other). But see Davis v. Mann, 377 U.S. 678, 692 (1964) (rejecting the balancing of urban and rural power as a grounds for upholding districts of unequal population); Comment, supra note 1, at 999 ("to preserve the two party system by guaranteeing a single party control of a legislative house is to destroy the purpose of that system").

In a pure republican polity, redistricting is an irrelevant concern because civic virtue, not parochialism, motivates legislators. $C f$. United Jewish Organizations v. Carey, 430 U.S. 144, 166 \& n.24 (1977) (finding that Hasidic Jews drawn into minoritydominated districts still would be represented by Hasidic Jews in nonminority districts, thus implying those Hasidic Jews in minority-dominated districts should rely on virtual, not actual, representation); Black, supra note 96, at 140-41 (maintaining that a system of virtual representation currently exists in the United States, given that legislators represent both those who supported their opponents and those who did not vote, as well as their own supporters); Neal, supra note 50, at 279 ("representatives from 'rural' districts also serve as spokesmen for some voters in 'urban' districts"); Rogowski, supra note 36 , at $424-25$ ("a bloc vote is usually more powerful as a strong minority in many constituencies than as a majority in only a few"). But see R. HANSON, supra note 32, at 7 (noting the vehement criticism of the colonists of the system of virtual representation before the revolution); Michelman, supra note 153, at 51-54 (analyzing the colonists' critique of the British virtual representation system); Comment, supra note 1, at $991 \mathrm{n} .113$ (same, noting the grievances catalogued in the Declaration of Independence).

${ }_{178}$ See Duverger, supra note 115 , at $36-38$ (explaining why majority rule is preferable to proportional representation); Hermens, supra note 115, at 19-23 (arguing that proportional representation promotes instability); see also Bickel, supra note 178, at 41 (citing the Weimar and French Fourth Republics as examples of the deleterious effects of proportional representation); Kirkpatrick, Democratic Elections, Democratic Government and Democratic Theory, in Democracy at the Polls 325, 340 (1981) (tying the collapse of the Weimar Republic to its excessive reliance on proportional representation at the expense of other values such as stability and majoritarianism). But see Hallett, supra note 115, at 119-24 (claiming that proportional representation enhances minority participation); Lakeman, supra note 115, at 47-49 (arguing that pro- 
a " 'unitary' state of common interests, the less it requires political equality."180

While both the White and O'Connor opinions may be discussed in terms of Professor Sunstein's deliberative democracy model, a constitutional requirement of the equally effective vote-proportional representation-cannot be placed on the spectrum. A constitutional requirement of proportional representation, essentially the reification of particular factions, is contrary to the pluralist model. Likewise, a constitutional requirement of proportional representation is inconsistent with the republican model because it suggests that something other than civic virtue motivates legislative decisionmaking. ${ }^{181}$

The inconsistency between requiring proportional representation and the Constitution can be demonstrated more directly. A "better" form of proportional representation would not stop with redistricting, but would instead require that each member of Congress have an equally effective vote in representing the effective votes of her constituents. To make that vote effective, the member would be entitled to "win" a proportionate number of votes in Congress. ${ }^{182}$ Certainly no one suggests that the Constitution requires such an outcome.

Finally, an expansive notion of an effective vote also clashes with

portional representation minimizes adversarial politics); Note, supra note 106 , at $175-$ 82 (arguing that the Constitution mandates proportional representation). For the importance of participation, see Baker, supra note 174, at 960-63 (outlining the political participation principle of the equality of respect model of equal protection). See generally B. CAIN, supra note 84, at 2 (arguing that political gerrymandering reduces participation); Lawson, Challenging Regulation of Political Parties: The California Case, 2 J.L. \& Pol. 263, 263-65 (1985) (noting the role of political parties in promoting participation); Powell, Voting Turnout in Thirty Democracies: Partisan, Legal, and Socio-Economic Influences, in Controversies IN Voting Behavior 34, 39-40 (R. Niemi \& H. Weisberg eds. 2d ed. 1984) (presenting empirical data documenting that proportional representation encourages participation).

${ }^{180}$ Mansbridge, supra note 153 , at 469 ; see also Moeller, supra note 70 , at 212 13 (claiming that the Court is a political actor yet has refused to be accommodating in redistricting). But see Backstrom, Robins \& Eller, supra note 1, at 1122 n.9 ("partisan gerrymandering is a major concern . . . in a system dominated by party politics").

$181 C f$. Bennett, supra note 154, at 1020 ("[E]ven the most effective statesmanship provide[s] insufficient protection for the politically weak."). Both Bennett and this Comment recognize the tension between Sunstein's model and the "equally effective vote" guaranteed in Reynolds. Unlike Bennett, however, this Comment challenges whether the Constitution literally guarantees an "equally effective vote."

${ }_{182}$ See Grofman \& Scarrow, The Riddle of Apportionment: Equality of What?, 70 Nat'L. Grvic REv. 242, 247-48 (1981) (examining the argument for "effective" representation); Lowenstein, supra note 5, at 12 (asking "[a]m I deprived of equal protection if my state legislator is a drunkard, has a high absentee rate, rarely authors bills that are enacted, and is generally regarded as ineffective"); $c f$. Kilgarlin v. Hill, 386 U.S. 120, 126 (1967) (Douglas, J., concurring) (allowing each person in a multimember district to vote for only one legislator ensures that "a minority, either political or otherwise, would have a chance to elect at least one representative"). 
other decisions by the Court that deny the existence of other "effective" constitutional rights. For example, the Constitution protects speech but it does not guarantee effective speech. ${ }^{183}$ Logically, the Constitution recognizes the right to an equal vote, but not the right to an equally effective vote. ${ }^{184}$

Thus a requirement of proportional representation cannot be rec-

183 See Miami Herald Publishing Co. v. Tornillo, 418 U.S. 241, 258 (1974) (invalidating state law requiring newspapers to publish political candidates' responses to editorials); see also Baker, Scope of the First Amendment Freedom of Speech, 25 UCLA L. REV. 964, 985-90 (1978) (rejecting the market failure interpretation of first amendment doctrine); $c f$. United States v. Saylor, 322 U.S. 385, 389 (1944) (stuffing of ballot boxes infringes upon right to have valid ballots accurately counted); United States v. Mosley, 238 U.S. 383, 386 (1915) (requiring that all valid ballots cast be counted).

This analogy to speech can be extended. Districting is a permissible time, place, and manner regulation of voting. See, e.g., CAL. Elec. CoDE $\$ 17$ (West 1977) (defining elector in terms of United States citizenship, age, place of residence, and length of residence); N.Y. El.k. L. LAW § 5-102 (McKinney 1978) (same); R.I. GEN. LAwS $\S 17-1-3$ (1986 Supp.) (same); see also U.S. CoNST. amend. XIV, \& 5 (authorizing state legislatures to prescribe the "times, places and manner of holding elections for senators and representatives). "The power to regulate the time, place, and manner of elections does not justify, without more, the abridgment of fundamental rights, such as the right to vote ...." Tashjian v. Republican Party, 107 S. Ct. 544, 550 (1986) (Connecticut closed primary statute limiting primary vote to registered party members impermissibly interfered with the party's right to extend the vote to independent voters). Hence, political gerrymandering may simply be viewed as an invalid time, place, and manner regulation. See Leading Cases, supra note 5, at 159 n.44 (noting that several of the amici in Davis made such an argument, which the Court declined to address); $c f$. Lowenstein, supra note 5, at 15 (arguing that Davis is not a "fundamental rights" case).

184 See Shapiro, supra note 69, at 232 (pointing out the contradiction in Reynolds). Compare Reynolds v. Sims, 377 U.S. 533, 565 (1964) ("[E]ffective participation by all citizens in state government requires . . that each citizen have an equally effective voice in the election of members of his state legislature.") with id. at 579 ("the overriding objective must be substantial equality of population among the various districts"). Lowenstein and Steinberg interpret the "equally effective vote" language in Reynolds to mean the marginal voter whose sole vote determines the outcome of the election. Since very few congressional and state legislative elections are decided by a single vote, Lowenstein and Steinberg suggest that the probability of the marginal voter playing a decisive role is akin to the risk of being "run over by a truck on the way to the polling place." Lowenstein \& Steinberg, supra note 104, at 14 n.38. Of course, their argument withers empirically in the face of the relatively small populations of state legislative districts in states such as Rhode Island, New Hampshire, and Delaware. Their argument also is flawed logically because it mistakenly assumes that an individual votes in a vacuum. Any observer of politics should recognize that a highly competitive election draws a higher voter turnout than a noncompetitive contest; each voter thinks she could be the marginal voter. $C f$. Lucas v. Forty-Fourth Gen. Assembly, 377 U.S. 713, 750 n.12 (1964) (Stewart, J., dissenting) ("electoral systems are intended to serve functions other than satisfying mathematical theories"); Dexter, supra note 104 , at 158-66 (recognizing communication areas; culture and social groups; interests, traditions, legislative efficiency and efficacy; and social invention as other redistricting criteria); Still, supra note 93, at 382-83 (positing that one requirement of political equality is anonymity). 
onciled with the deliberative democracy understanding of the Constitution. Yet six members of the Court in Davis inched down the Reynolds slippery slope toward proportional representation. Conscious of this tension, the six justices produced two divergent sets of equal protection standards in an attempt to brake the slide.

\section{B. Equal Protection Standards}

Justice White characterized an equal protection claim based on political gerrymandering as comprised of two components: (1) "intentional discrimination against an identifiable political group" and (2) "an actual discriminatory effect on that group."185 By neglecting to define "discriminatory effect," however, Justice White failed to explain why one is a necessary condition of an equal protection claim. Justice Powell, on the other hand, held that an invidious intent to discriminate alone could be sufficient to invalidate a redistricting scheme. ${ }^{186}$

Both opinions reject a political process explanation for redistricting ${ }^{\mathbf{1 8 7}}$ because implicit in each opinion is a recognition that redistricting is not a value-neutral process that can be remedied by mechanically rectifying the ability of discrete and insular groups to participate. Rather, both opinions comport with an equality of respect model of equal protection. As presented by Professor Baker, the equality of respect model is based on three principles:

First, the state must recognize the fundamental nature of people's right to participate in a political process that chooses and attempts to implement the group's conception of the good society-a political participation principle. Second, the state must not pursue purposes, and the political process must not further individuals' preferences, to subordinate or to denigrate the inherent worth of any category of citizens. Third, the state must guarantee to everyone those resources and opportunities that the existing community treats as necessary for full life and participation in that community. ${ }^{188}$

185 Davis, 106 S. Ct. at 2808.

${ }^{186}$ See Davis, 106 S. Ct. at 2832 n.12 (Powell, J., concurring and dissenting) ("[P]roof of grotesque district shapes may, without more, provide convincing proof of unconstitutional gerrymandering.").

${ }^{187} C f$. J. ELY, supra note 37, at 77 ("[E]qual participation in the processes of government is by no means self-evidently linked to . . . equal participation in the benefits and costs that process generates."). For a critique of the political process approach, see Baker, supra note 108, at 1041-70; Regan, Community and Justice in Constitutional Theory, 1985 WIS. L. REv. 1073, 1108-23.

${ }^{188}$ Baker, supra note 174, at 959. But see Sherry, Selective Judicial Activism in the Equal Protection Context: Democracy, Distrust, and Deconstruction, 73 Geo. L.J. 
In the voting context the equality of respect model emphasizes an objective analysis of "how the state treats the person's act, the person's vote." ${ }^{\text {"189 }}$ Thus, Section B of this Part analyzes the opinions of both Justices White and Powell and concludes that Justice Powell's opinion is preferable because it is articulated more clearly and relies more heavily, although not completely, on an objective approach.

\section{Justice White's Opinion}

\section{a. Assuming Discriminatory Intent}

Not every disparate impact is the product of an invidious intent to discriminate. ${ }^{180}$ Consequently, the plaintiff in an equal protection action must show evidence of an invidious intent. ${ }^{101}$ Redistricting presents

89, 102 (1984) (arguing that "[t]he theoretical basis for [Baker's model] casts us adrift from the Constitution... insofar as it leaves us neither with answers nor with any justifiable way of approaching the questions").

189 Baker, supra note 108 , at 1079.

180 See, e.g., Wayte v. United States, 470 U.S. 598, 609-10 (1985) (sustaining the prosecution of active objector to draft registration absent proof of an invidious intent to violate first amendment rights); Village of Arlington Heights v. Metropolitan Hous. Dev. Corp., 429 U.S. 252, 270 (1977) (sustaining a city zoning ordinance in the absence of proof of an invidious intent to discriminate on the basis of race); Washington v. Davis, 426 U.S. 229, 246 (1976) (sustaining a police department hiring policy in the absence of an invidious intent to discriminate on the basis of race).

An additional, yet important, question that is beyond the scope of this Comment is what consistutes "an identifiable group," see Davis, 106 S. Ct. at 2808, against whom there is purposeful discrimination. See United States v. City of Los Angeles, No. GV 85:7739 JMI (JRx), slip op. at 2 (C.D. Cal. Sept. 10, 1986) (refusing to allow homeowners' group to intervene in a redistricting suit); see also Lowenstein, supra note 5 , at 10-11 (asking whether "Democratic voters" means those who voted for Democrats in a particular election, those who vote for Democrats generally, those who called themselves Democrats, or those who formally register with election officials as Democrats).

191 See Wayte, 470 U.S. at 608; Arlington Heights, 429 U.S. at 265-68; Washington, 426 U.S. at 239-45; see also Baker, supra note 174, at 972-84 (demonstrating that the no subordinating purpose principle of the equality of respect model most coherently explains equal protection case law); Raveson, Unmasking the Motives of Government Decisionmakers: A Subpoena For Your Thoughts?, 63 N.C.L. REv. 879, 883-89 (1985) (arguing that the Court's reinvigoration of intent analysis amounts to a reassessment of the separation of powers doctrine); Simon, Racially Prejudiced Governmental Actions: A Motivation Theory of the Constitutional Ban Against Racial Discrimination, 15 SAN Diego L. REv. 1041, 1054 (1978) (when evaluating facially neutral enactments, the Court's evidentiary issue is "would the government have taken the same action apart from prejudice?"); Note, To Infer or Not to Infer a Discriminatory Purpose: Rethinking Equal Protection Doctrine, 61 N.Y.U. L. REv. 334, 341-43 (1986) (criticizing the Court for substituting a rigid interpretation of intent in recent cases for the flexible standard adopted in Arlington Heights and Washington). But see Palmer v. Thompson, 403 U.S. 217, 223-24 (1971) (refusing to inquire into a city council's motives for closing city-owned swimming pools after a desegregation order); United States v. O'Brien, 391 U.S. 367, 383-84 (1968) (refusing to inquire into Congress's motives for amending the Selective Service Act to prohibit the knowing destruction of draft cards); Fletcher v. Peck, 10 U.S. (6 Cranch) 87, 130 (1810) (stating that 
a particularly peculiar problem for motivational analysis. Justice White aptly noted that there are no neutral lines for legislative districts: "[E]very line drawn aligns partisans and interest blocs in a particular way different from the alignment that would result from putting the line in some other place." "182 Similarly, Justice White rejected the suggestion that those who redistrict eschew political data such as past voting patterns and party registration statistics: ${ }^{193}$

[T]his politically mindless approach may produce, whether intended or not, the most grossly gerrymandered results; and, in any event, it is most unlikely that the political impact of such a plan would remain undiscovered by the time it was proposed or adopted, in which event the results would be both known and, if not changed, intended. ${ }^{104}$

Justice White recognized that voters of both political parties are neither uniformly distributed nor rigidly segregated in any state. ${ }^{195}$ Recognizing a problem, however, is not the same as solving it by offering a workable standard. In Davis, Justice White appeared to presume a discriminatory intent: "As long as redistricting is done by a legislature, it should not be very difficult to prove that the likely political consequences of the reapportionment were intended."186 Yet Justice White qualified this assumption with a footnote stating that a plaintiff still must prove discriminatory intent. ${ }^{107}$ What Justice White gave with one

the Court should approach with "much circumspection" an inquiry into the motives for repealing a land grant).

182 Davis, $106 \mathrm{~S}$. Ct. at 2808 n.10 (quoting Dixon, supra note 84, at 7-8); see also Bennett, supra note 154, at 1010-11 (recognizing that any apportionment decision will affect minority groups in some way).

183 See supra notes $126-27$ and accompanying text.

194 Davis, 106 S. Ct. at 2808 (quoting Gaffney v. Cummings, 412 U.S. 735, 753 (1973)). The district court in Gaffney actually tried to draft its own plan as an alternative to the one ultimately upheld by the Court. The special master, then-Professor Robert Bork, did not rely on political data. "His resultant plan, though it certainly was not his intent, was so favorable to the Democratic party that . . . he was specially congratulated by the state Democratic chairman . . . Dixon, supra note 84, at 18-19; see also P. MusGrove, supra note 6, at 6 (explaining why results-driven gerrymandering would exist even if redistricting were somehow randomized, thus eliminating intent).

198 If all voters were uniformly distributed across the state, the majority party would capture every district. See Lowenstein \& Steinberg, supra note 104, at 6 \& n.16. In contrast, if all voters were segregated by district according to party affiliation, each party would capture districts equal to its proportion in the population. See Still, supra note 93, at 384-85. Of course neither of these conditions exists in any state. But see Karst, supra note 8, at 346-51 (ethnic gerrymandering signifies legislative awareness of cultural politics and discernible patterns of ethnic voting). In practice, however, singlemember districting has tended to benefit the majority party. See Backstrom, Robins \& Eller, supra note 1 , at 1134 n.43.

188 Davis, 106 S. Ct. at 2809.

197 See id. at 2809 n.11 ("That discriminatory intent may not be difficult to prove 
hand, he took with the other.

\section{b. Ascertaining Actual Discriminatory Effect}

Justice White had little more success in trying to establish a discriminatory effect standard. Under his analysis, "unconstitutional discrimination occurs only when the electoral system is arranged in a manner that will consistently degrade a voter's or a group of voters' influence on the political process as a whole."198 Justice White drew on the racial gerrymandering precedents and focused on the ability of a particular group to influence the political process. ${ }^{189}$ But he set a high standard of proof, requiring the plaintiff to show a "continued frustration of the will of a majority of the voters or effective denial to a minority of voters of a fair chance to influence the political process."

Justice White's discriminatory effects standard is open to attack on two grounds. First, "consistent degradation," like the "equally effective" requirement in Reynolds, is another example of the Court trying to use one rule to accomplish two goals. ${ }^{201}$ "Gonsistent degradation" has both a temporal and a spatial quality. In the temporal context, "consistent degradation" is particularly hard to prove because many states hold state legislative elections only two or three times during a decennium. ${ }^{202}$ In the spatial context, "consistent degradation" is difficult to ascertain because it presumes that some unknown de minimis threshold exists below which a discriminatory effect is tolerable. ${ }^{203}$

Second, Justice White's focus on effects requires the Court "to describe the required outcomes or to identify principles with which one can determine required outcomes [and] to justify requiring these out-

in this context does not, of course, mean that it need not be proved at all to succeed on such a claim.").

188 Id. at 2810.

199 See id. at 2809-10.

$200 \mathrm{Id}$. at 2811.

${ }^{201}$ Tinbergen's rule explains the particular problem with Justice White's standard: the number of policy variables must be at least equal to the number of policy ends. See J. Tinbergen, On the Theory of Economic Policy 39 (1952).

202 Compare Davis, $106 \mathrm{~S}$. Ct. at 2814 (rejecting the claim of plaintiff Indiana Democrats for lack of proof because proof was based on only one election) with id. at 2814 n.17 (suggesting future plaintiffs can make claims based on projected election results). Thirty-seven states have four-year terms for members of the upper chamber of their state legislatures. Nebraska has a four-year term for its unicameral, nonpartisan state legislature. Alabama, Louisiana, Maryland, and Mississippi have four-year terms for members of both houses of their state legislatures. See THE Council OF STATE Government, The Book of The States 87 (1986).

${ }_{203}$ See Leading Cases, supra note 5, at 161. In his discussion of the Israeli Knesset, Professor Levinson raises the counterpoise to Justice White's problem-in a system of proportional representation, at what level is a group entitled to representation? See Levinson, supra note 93, at 273-74. 
comes." 204 But Justice White conceded that "there are no neutral lines for legislative districts . . . every line drawn aligns partisans and interest blocs in a particular way different from the alignment that would result from putting the line in some other place."206 Justice White's reliance on projected election results when no election has occurred to set the standard for comparing the redistricting scheme with the required outcome $\mathrm{e}^{206}$ is disingenuous at best.

\section{Justice Powell's Opinion}

In contrast, Justice Powell relied on a more contextual approach to invalidate the Indiana redistricting plan. Justice Powell's approach was based on Justice Stevens's concurrence in Karcher v. Daggett ${ }^{207}$ three years earlier. Not surprisingly, Justice Stevens concurred with Justice Powell in Davis. Unlike Justice White, Justice Powell indicated that showing a discriminatory effect was not a necessary condition of a political gerrymandering claim. ${ }^{208}$ An invidious intent was sufficient.

Justice Powell used compactness as a contextual standard to infer an invidious intent. First, a court should consider whether any districts are irregularly shaped. ${ }^{209}$ Irregularly shaped districts are potentially a sufficient condition for a claim of political gerrymandering. ${ }^{210}$ Justice Powell cited the twenty-eight sided "dragon" in Gomillion v. Lightfoot"11 and the "fishhook" and "swan" in Karcher as providing convincing proof of a political gerrymander without any other evidence. ${ }^{212}$ Justice Powell, however, failed to establish any standard by

204 Baker, supra note 174, at 935.

${ }^{205}$ Davis, 106 S. Ct. at 2808 n.10 (quoting Dixon, supra note 84, at 7-8); see also P. MusGrove, supra note 6 , at 6 (explaining why if gerrymandering is defined in terms of effects, even a randomly-generated redistricting plan is a gerrymander); Backstrom, supra note 101, at 46 ("Give a chimp in a 200 a crayon and a map, and the resulting plan will have differential effects on people.").

${ }^{200}$ See Davis, 106 S. Ct. at 2814 n.17; cf. Cahn, Jurisprudence, 30 N.Y.U. L. REv. 150, 167 (1955) (questioning whether the guarantee of fundamental rights should "rise, fall, or change along with the latest fashions of psychological literature"). But see Hess, supra note 5, at 229 (advocating an "effects" test as distinguished from a results test (citing Backstrom, Rọbins \& Eller, supra note 1, at 1131-39)).

${ }_{207} 462$ U.S. 725 (1983) (Stevens, J., concurring).

${ }^{208}$ See Davis, 106 S. Ct. at 2831 n.10 (Powell, J., concurring and dissenting).

${ }^{209}$ Id. at 2832 (Powell, J., concurring and dissenting).

210 Id. at 2832 n.12 (Powell, J., concurring and dissenting); $c f$. Wayte v. United States, 470 U.S. 598, 608 n.10 (1985) (Powell, J.) ("A showing of discriminatory intent is not necessary when the equal protection claim is based on an overtly discriminatory classification.").

211364 U.S. 339 (1960).

212 See Davis, 106 S. Ct. at 2832 n.12 (Powell, J., concurring and dissenting) (citing the redistricting maps appended to Gomillion, 364 U.S. at 348, and Karcher, 
which to determine if a district is "appropriately" shaped. Justice Powell's reliance on shape is troublesome because irregular shapes may have rational purposes unrelated to political gerrymandering. ${ }^{\mathbf{2 1 3}}$

The second compactness factor Powell considered is the adherence to established political subdivision boundaries. ${ }^{214}$ Political gerrymandering entails the "splitting" of communities to maximize political control. ${ }^{215}$ As Justice Powell noted, however, "[i]ntelligent voters, regardless of party affiliation, resent this sort of political manipulation of the electorate for no public purpose."216 Moreover, "[i]ndiscriminate districting, without any regard for political subdivision or natural or historical boundary lines, may be little more than an open invitation to partisan gerrymandering." ${ }^{217}$ Maintaining the integrity of political subdivisions enables citizens to "focus their political activities." 218 On the other hand, focusing on the boundaries of political subdivisions is problematic in two ways. First, it is constitutionally problematic in light of Reynolds because "[l] egislators are elected by voters, not farms or cities or economic interests." ${ }^{219}$ Second, the standard is politically problematic

462 U.S. at 744). Justice Powell also suggested that Indiana House District 66 in the Davis plan "perhaps most closely resembles a salamander." Id. at 2827 n.3 (Powell, J., concurring and dissenting); see also id. at 2840 (map of house district 66).

${ }_{213}$ See B. CAIN, supra note 84, at 50-51 (noting that compactness creates a bias in favor of the majority, thus implying that strangely-shaped districts may be rationally related to the goal of minority representation); P. MUSGROVE, supra note 6, at 52-54 (arguing that a compactness standard creates a bias towards the party that can best gerrymander while simultaneously drawing compact districts); see also Sickels, supra note 6 , at 1300 ("strained shapes are not always reliable signs that partisan . . . interests are being served, while the most regularly drawn district may [have been intended] to aid one party"); cf. Dixon, supra note 1, at 249 (questioning what value contiguity of districts serves "[g]iven the realities of modern communication and of anomie with one's neighbors"); Lowenstein \& Steinberg, supra note 104, at 22 (questioning what value compactness of districts serves with modern transportation and communication).

${ }^{214}$ See Davis, 106 S. Ct. at 2832 (Powell, J., concurring and dissenting).

215 See, e.g., Shayer v. Kirkpatrick, 541 F. Supp. 922, 934 (W.D. Mo.) (requiring for reapportionment that the state first approach population equality and then designate "compact and contiguous" districts), affd sub nom. Schatzle v. Kirkpatrick, 456 U.S. 966 (1982); State ex rel. Lockert v. Crowell, 631 S.W.2d 702, 714-15 (Tenn. 1982) (same).

${ }_{216}^{16}$ Davis, 106 S. Ct. at 2833-34 (Powell, J., concurring and dissenting). But see Lowenstein \& Steinberg, supra note 104, at 23-35 (arguing that attempts to prohibit splitting are not politically neutral because they tend to advance the interests of the Republican party). Implicit in Lowenstein and Steinberg's argument is the reality of contemporary demographics. But see Shapiro, supra note 69, at 238 (noting Lowenstein and Steinberg's paradoxical view that "[o]nly an affirmative gerrymander in favor of the Democratic Party will result in ungerrymandered districts").

217 Reynolds, 377 U.S. at 578-79.

218 Davis, 106 S. Ct. at 2832 n.13 (Powell, J., concurring and dissenting).

210 Reynolds, 377 U.S. at 562. But see Brown v. Thompson, 462 U.S. 835, 84546 (1983) ("The consistency of application and the neutrality of effect of the nonpopulation criteria must be considered along with the size of the population disparities in determining whether a state legislative apportionment plan contravenes the Equal Pro- 
because the representation of a political subdivision is enhanced when it is divided; that is, a community has two representatives rather than one. 220

Justice Powell also held that the context in which a plan was adopted is relevant. ${ }^{221}$ Consistent with the equality of respect model, rectification of procedural deficiencies is not sufficient to correct an otherwise purposeful political gerrymander. ${ }^{222}$ If such rectification were sufficient, a legislature could cure an unconstitutional plan by adding a few public hearings or a few members of the subordinate party to the redistricting authority. ${ }^{223}$ Thus meaningful political participation is key.

Obviously, the opinions of Justices Powell and White are flawed. Justice Powell's opinion is preferable, however, because it is better articulated. First, by focusing on compactness and the existence of participation, Justice Powell's opinion is easier for lower courts to follow. Second and more importantly, Justice Powell's opinion explicitly recog-

tection Clause."); Abate v. Mundt, 403 U.S. 182, 185 (1971) (stating that "the particular circumstances and needs of a local community as a whole may sometimes justify departures from strict equality").

${ }_{220}$ See Lowenstein \& Steinberg, supra note 104, at 27-35. But see Dexter, supra note 104, at 158-59 (splitting a community defeats its voters' senses of efficacy and competence); Niemi, Powell \& Bicknell, The Effects of Congruity Between Community and District on Salience of U.S. House Candidates, 11 LEgIS. STuD. Q. 187, 193 (1986) (demonstrating empirically that the more a community is divided into districts, the less familiar or recognized a candidate becomes).

Justice Powell's proposal is also problematic because it assumes that political subdivisions are compact. But see Lowenstein \& Steinberg, supra note 104, at 34 n.91 (citing Gaffney v. Cummings, 412 U.S. 735, 752 n.18 (1973) ("[A]ny plan that attempts to follow Connecticut's 'oddly shaped' town lines . . . is bound to contain some irregularly shaped districts."); B. CAIN, supra note 84, at 46 (enumerating strangely shaped California cities that compete with "the most creative efforts of gerrymanderers over the years")); see also Legislature v. Reinecke, 10 Cal. 3d 396, 413, 516 P.2d 6, 17, 110 Cal. Rptr. 718, 729 (1973) (Appendix, Report and Recommendations of Special Masters on Reapportionment) ("Some cities have exceedingly irregular boundaries with an odd assortment of 'fingers' and 'peninsulas' jutting out from the basic part of the city.").

221 See Davis, 106 S. Ct. at 2832-33 (Powell, J., concurring and dissenting). For example, in Davis, the reapportionment act was a "vehicle bill," the details of which were decided by a legislative Conference Committee which denied effective membership to the subordinate party. Four members of the subordinate party served as "advisors" to the committee. The "advisors" were excluded from the mapmaking process and were denied voting privileges. In drafting the actual plan, the Conference Committee relied on the computer technology of the dominant party's political organization. No member of the public or the subordinate party had access to either the computer program's input or output. The Conference Committee never held promised hearings for voters to air their concerns. Finally, when the bill was reported by the Conference Committee, the subordinate party had only 40 hours to review the districting of 4000 precincts. Id. at 2833 (Powell, J., concurring and dissenting).

222 See Baker, supra note 174 , at 978.

${ }^{223}$ See $i d$. A legislator would call such a hearing a dog and pony show. 
nizes the primacy of invidious purpose in analyzing political gerrymandering claims, whereas Justice White's opinion minimizes the implications of such an inquiry. Indeed, Justice White's criticism of Justice Powell's decision is contradictory. According to Justice White, Justice Powell's factors "support a finding that an intention to discriminate was present and that districts were drawn in accordance with that intention, but they do not show any actual disadvantage beyond that shown by the election results...."224

\section{Hide and SeEk: SpeEch oR Debate}

"[T]he ubiquity of the tendency to see the world [in terms of reducing all collective wholes into their individual parts] may partially explain why most lawyers and legal theorists assume that the real concern in the motive/purpose inquiry must be with individual subjective motives ...."225 Hence, not suprisingly, the opinions of Justices White and Powell in Davis v. Bandemer ${ }^{228}$ and Justice Stevens in Karcher $v$. Daggett ${ }^{227}$ all refer to the subjective motivations of legislators in developing redistricting plans. ${ }^{228}$ This Section of this Comment explains why an attempt to analyze the subjective motivations of legislators is fraught with problems of proof.

Theoretically, an easy and obvious way to establish subjective intent is to discover clearly nonprivileged communications of state legislators. ${ }^{229}$ For example, in Karcher, Justice Stevens made pointed use of a letter signed by the Speaker of the New Jersey House of Representatives. In that letter, the Speaker, a Democrat, tried to justify political gerrymandering on the ground that the New Jersey Republican Party had politically gerrymandered in the past. ${ }^{230}$ In the 1990 redistricting

224 Davis, 106 S. Ct. at 2814.

225 Baker, supra note 173 , at 974 ; see, e.g., Raveson, supra note 191, at 883 (referring to the Court's increasing attention to the subjective intent of decisionmakers); Sunstein, supra note 153 , at 79-81 (discussing methods for identifying and handling legislative and administrative motivations).

228106 S. Ct. 2797 (1986).

227462 U.S. 725 (1983).

${ }^{228}$ See Davis, 106 S. Ct. at 2802 n.5; id. at 2834 (Powell, J., concurring and dissenting); Karcher, 462 U.S. at 763-64 (Stevens, J., concurring).

${ }_{228}$ See, e.g., Karcher, 462 U.S. at 763-64 (Stevens, J., concurring) (letter from state legislator outlining purposes behind redistricting admitted as evidence); In re Orans, 45 Misc. 2d 616, 643-44, 257 N.Y.S.2d 839, 865 (N.Y. Sup. Ct.) (letter from a state legislator may be used as an admission against interest), affd, 15 N.Y.2d 339, 206 N.E.2d 854, 258 N.Y.S.2d 825, appeal dismissed, 382 U.S. 10 (1965); see also Raveson, supra note 191, at $946 \mathrm{n} .412$ (discussing the scope and ramifications of different discovery tools).

${ }^{230}$ See Karcher, 462 U.S. at 763-64 (Stevens, J., concurring). The district court reproduced the letter in its entirety. See Daggett v. Kimmelman, 535 F. Supp. 978, 
cycle, however, legislators will not leave such an obviously incriminatory paper trail. ${ }^{\mathbf{2 3 1}}$ With the advent of the justiciability of political gerrymandering, legislative candor, such as that seen in Karcher, will disappear. ${ }^{\mathbf{2 3 2}}$

A second way to establish subjective intent is to depose legislators. If plaintiffs rely on depositions, however, legislators may make use of the speech or debate clauses of state constitutions to avoid testifying. ${ }^{233}$ This immunity appears in most state constitutions ${ }^{234}$ and is usually - modeled after the analogous federal constitutional provision for Congress. ${ }^{235}$ The purpose of the immunity is not to protect any particular kind of speech but generally to insulate legislators from intimidation by co-equal branches of government, a separation of powers argument, and to prevent time-consuming distraction. ${ }^{236}$ This reliance on both purposes, however, is debatable because the immunity to suit does not protect all lawmaker conduct. ${ }^{237}$

989-93 (D.N.J. 1982). See generally Weinstein, supra note 133, at 358-59 (explaining the context in which Karcher arose).

${ }^{231}$ Cf. City of Mobile v. Bolden, 446 U.S. 55, 135 (1980) (Marshall, J., dissenting) (warning that legislators may still adopt discriminatory policies if they are able to "mask their motives through the use of subtlety and illusion").

${ }^{232}$ See Baker, supra note 31, at 14; Hess, supra note 5, at 239; Raveson, supra note 191, at 926 \& n.312. But see Weinstein, supra note 133, at 374 (arguing that redistricting is an inherently public enterprise, thus making proof of intent "readily available in many cases").

${ }^{233}$ See Holmes v. Farmer, 475 A.2d 976, 983 (R.I. 1984) (legislators and aides relying on privilege). But see Bush v. Martin, 251 F. Supp. 484, 495 n. 40 (S.D. Tex. 1966) (legislators and aides not relying on privilege).

${ }_{2 s 4}$ See, e.g., Colo. Const. art. V, § 16; N.Y. Const. art. III, § 11; R.I. Const. art. IV, $\S 5$.

${ }^{235}$ See U.S. CoNST. art. I, $\S 6$ ("[F]or any Speech or Debate in either House [the Senators and Representatives] shall not be questioned in any other Place."); see also Cella, The Doctrine of Legislative Privilege of Freedom of Speech and Debate: Its Past, Present and Future as a Bar to Criminal Prosecutions in the Courts, 2 SufFOLK U.L. REv. 1, 2-3 (1968) (noting that the language of the legislative privilege in some state constitutional provisions is actually more liberal than the language in the analogous federal provision); Raveson, supra note 191, at $913 \mathrm{n} .241$ (although most state constitutions provide state legislators with analogous speech or debate privileges, "the individual clauses differ widely, both in applicability and scope").

${ }^{236}$ See Eastland v. United States Servicemen's Fund, 421 U.S. 491, 502-03 (1975); United States v. Johnson, 383 U.S. 169, 180 (1966); Tenney v. Brandhove, 341 U.S. 367, 373 (1951); Fletcher v. Peck, 10 U.S. (6 Cranch.) 87, 130 (1810); Miller v. Transamerican Press, Inc., 709 F.2d 524, 528 (9th Cir. 1983); Holmes, 475 A.2d at 982; see also Raveson, supra note 191, at 923 (noting that the speech or debate clause prohibits legislators' compelled testimony in order to protect "freedom from time-consuming distraction and freedom from intimidation"); Note, The Scope of Immunity for Legislators and Their Employees, 77 YALE L.J. 366, 385 (1967) (arguing that considered individually, the distraction and separation of powers arguments are insufficient, but when considered together they "add up to a fairly coherent view of the scope of the privilege").

297 See, e.g., Hutchinson v. Proxmire, 443 U.S. 111, 133 (1979) (explaining that 
Typically, the immunity covers legislators and their aides, on the theory that legislators cannot personally perform all their functions. ${ }^{\mathbf{2 3 8}}$ Even in states in which the state constitution does not explicitly provide for the immunity, the Court has found a general common law legislative immunity to suit for official actions. ${ }^{239}$ This immunity sometimes extends to bodies acting in a quasi-legislative capacity. ${ }^{\mathbf{2 4 0}}$.

The courts have not definitively resolved, however, whether the immunity to suit also creates an evidentiary privilege. ${ }^{241}$ The Court held in Village of Arlington Heights v. Metropolitan Housing Development Corp. ${ }^{242}$ that, in unusual circumstances, a plaintiff can call individual legislators to testify as proof of subjective intent. ${ }^{243}$ The Court then noted, however, that "such testimony frequently will be barred by privilege." 244 But the Court failed to give any content to the term "fre-

the privilege does not apply to remarks of United States senator made off the Senate floor); Davis v. Passman, 442 U.S. 228, 235 n.11 (1979) (stating that the privilege does not apply to the hiring practices of members of Congress); Eastland, 421 U.S. at 511 n.17 (stating that the privilege does not excuse a senator from answering a complaint); Gravel v. United States, 408 U.S. 606, 627-29 (1972) (noting that a senatorial aide may not claim privilege if no legislative action is implicated); see also Note, Evidentiary Implications of the Speech or Debate Clause, 88 YALE L.J. 1280, 1298 (1979) (arguing that the privilege should not apply to nonlegislative acts regardless of the nexus between those acts to legislative acts).

${ }^{238}$ See, e.g., Holmes, 475 A.2d at 984 (explaining that "[f]or the purpose of construing the privilege, legislators and legislative aides are to be "treated as one" "quoting Gravel, 408 U.S. at 616)); State v. Beno, 116 Wis. 2d 122, 146, 341 N.W.2d 668, 680 (1984) (recognizing that legislators rely on their employees so that legislators do not have to perform all tasks personally). But see, e.g., Kilbourn v. Thompson, 103 U.S. 168, 197 (1880) (holding that when Congress exceeded its authority, sergeant-atarms cannot claim privilege).

${ }^{239}$ See Tenney, 341 U.S. at 376-79 (holding that state legislators are immune to suit for the same policy reasons that members of Congress are immune).

240 See Supreme Court v. Consumers Union of the United States, Inc., 446 U.S. 719, 731-34 (1980) (extending legislative privilege to the Virginia Supreme Court, which promulgates ethical standards for the Virginia bar); Lake Country Estates, Inc. v. Tahoe Regional Planning Agency, 440 U.S. 391, 400-02 (1979) (not extending legislative privilege to interstate planning board); $c f$. Hispanic Coalition on Reapportionment v. Legislative Reapportionment Comm'n, 536 F. Supp. 578, 583 n.4 (E.D. Pa.) (declining to consider issue of legislative immunity of members of reapportionment commission based on Supreme Court because complaint was dismissed on other grounds), affd, 459 U.S. 801 (1982).

${ }^{241}$ See Raveson, supra note 191, at 910. But cf. Holmes, 475 A.2d at 984 (citing United States v. Peoples Temple of the Disciples of Christ, 515 F. Supp. 246, 248-49 (D.D.C. 1981)) (the speech or debate clause "must be construed as an immunity from suit as well as a testimonial privilege."); Kerttula v. Abood, 686 P.2d 1197, 1204 (Alaska 1984) (citing Miller v. Transamerican Press, Inc., 709 F.2d 524, 530 (9th Cir. 1983)) (recognizing both an evidentiary privilege and an immunity from suit in the Alaskan speech or debate clause).

242429 U.S. 252 (1977).

243 See id. at 268.

244 Id.; cf. Marion v. Hall, 429 So. $2 d$ 937, 944 (Ala. 1983) (Torbert, C.J., concurring) (quoting United States v. Brewster, 408 U.S. 501, 525 (1972), for the proposi- 
quently."245 In state courts, the issue thus posed is whether judicial review of a challenged statute or redistricting plan takes precedence over the separation of powers. ${ }^{246}$ In federal courts, the issue is whether judicial review should be conditioned by state constitutional privileges. ${ }^{247}$

Notwithstanding these questions, procedural concerns also exist. For example, even if an evidentiary privilege does exist, to whom does it accrue? If it accrues to the legislative body and the body does not waive ${ }^{2},{ }^{248}$ then no individual legislator can testify as to her motivations or those of her colleagues. ${ }^{249}$ On the other hand, if it accrues to the individual, then only the individual can waive it. ${ }^{250}$

When the privilege exists-either by virtue of a constitutional provision or by judicial construct-and it is not waived, ascertaining subjective legislative intent can be extremely difficult. May $v$. Cooperman ${ }^{251}$ exemplifies this difficulty. In May, the Third Circuit considered the constitutionality of a New Jersey statute that required public schools to permit students to observe a one-minute period of silence "for quiet and private contemplation or introspection." 252 Since the principal issue was whether or not the statute implicated the first

tion that the speech or debate clause protects against inquiry into the motivation for legislative acts). White similarly struggled in Davis to ascertain legislative intent by creating a rule and then limiting it. See Davis, $106 \mathrm{~S}$. Ct. at 2809 \& n.11.

215 See Raveson, supra note 191 , at 913 n.238 (specifying that "[t]he Court did not indicate why and under what circumstances legislators might not be privileged to refuse to testify").

${ }^{248}$ Professor Raveson argues that judicial review takes precedence over the speech or debate clause, thus qualifying the privilege in the evidentiary context. See id. at 924 .

247 See id. at 913 n.241 (arguing that "separation of powers principles justify a lesser privilege for state legislators in civil proceedings than that afforded members of Congress"); cf. United States v. Gillock, 445 U.S. 360, 368 (1986) (refusing to recognize a state constitutional privilege in a federal criminal proceeding); In re Grand Jury Subpoena, 626 F. Supp. 1319, 1325-29 (M.D. Pa. 1986) (recognizing a common law privilege for state legislators who were not the target of a criminal investigation).

${ }_{248}$ See, e.g., State ex rel. Stephan v. Kansas House of Representatives, 236 Kan. 45, 56-58, 687 P.2d 622, 631-33 (1984) (sustaining motion to dismiss by the Kansas legislature on speech or debate grounds); $c f$. Note, The Bribed Congressman's Immunity from Prosecution, 75 YALE L.J. 335, 340-41 (1965) (noting that Congress has waived its privilege when it passes antibribery statutes).

248 See, e.g., Holmes v. Farmer, 475 A.2d 976, 984-85 (R.I. 1984) (sustaining the refusal of the trial court to hear an individual legislator's testimony on the ground that the legislature had not waived its institutional privilege); see also Raveson, supra note 191, at 938 (concluding that "[w]hether the institution ever should be permitted to waive the privilege for individual legislators is debatable").

${ }^{280}$ See, e.g., In re Grand Jury Proceedings, 563 F.2d 577, 585 (3d Cir. 1977) (stating that the privilege accrued to the individual lawmaker, not to the legislature as an institution).

${ }^{281} 780$ F.2d 240 (3d Cir. 1985), appeal filed sub nom. Karcher v. May, 107 S.

Ct. 946 (1987).

232 See id. at 241. 
amendment establishment clause, ${ }^{253}$ the court had to consider whether or not the legislation had a secular purpose. ${ }^{254}$ The Speaker of the New Jersey Assembly and the President of the State Senate intervened as defendants, ${ }^{205}$ but the district court ruled prior to trial that the plaintiffs could not depose the legislators. ${ }^{256}$

Judge Gibbons, for the majority, relied on the district court's objective contextual approach to ascertaining legislative purpose to sustain the district court's finding of an impermissible purpose. ${ }^{257}$ The district court had found that the tendered purpose of the moment of silence was a pretext because evidence suggested it had no pedagogical value. ${ }^{258}$ The district court also noted other, less facially neutral attempts to put prayer in the classroom, focusing particularly on the past actions of the sponsor of this legislation. ${ }^{258}$ Judge Gibbons brushed aside the defendant's objection to the use of newspaper clippings as superfluous in light of the hearsay testimony of educational experts and of witnesses who attended the committee hearings on the bill. ${ }^{260}$

In contrast, Judge Becker, writing in dissent, divided the evidence into five categories and analyzed each in isolation. First, the testimony of the witnesses who attended the hearings was "at best underwhelming" because it demonstrated only what two assemblymen thought about the issue. ${ }^{261}$ Second, the newspaper evidence did not satisfy any

${ }^{25 s}$ See U.S. Const. amend. I ("Congress shall make no law respecting an establishment of religion .....").

${ }^{284}$ See May, 780 F.2d at 246 (citing Lemon v. Kurtzman, 403 U.S. 602, 612-13 (1971)).

${ }^{255}$ See id. at 242. The procedural posture of May before the Court has been complicated by the fact that the defendant New Jersey legislature as a body withdrew its appeal to the Court in April 1986, leaving only the two state legislators (who no longer served in the same capacities in the state legislature) as defendants. At oral argument, "well over half of the hourlong argument, and most of the questions from all eight Justices centered on the Justices' evident doubts whether the two legislators had legal standing to appeal, and thus whether the Court itself had jurisdiction to determine the constitutionality of the law at all." Period of Silence Debated in Court, N.Y. Times, Oct. 7, 1987, at B10, col. 6; see also Minute of Silence, 56 U.S.L.W. 3177 (Sept. 22, 1987) (describing the arguments in the May litigation). See generally Brief for Amicus Curiae United States at 8-13, Karcher v. May, No. 85-155l (U.S. argued October 6, 1987) (arguing that the defendant-legislators lack standing).

256 See May, 780 F.2d at 252 n.9; see also May v. Cooperman, 572 F. Supp. 1561, 1561 n.2 (D.N.J. 1983).

287 See May, 780 F.2d at 251-52.

258 See id. (citing May, 572. F. Supp. at 1571).

${ }^{258}$ See id. at 252 (citing May, 572 F. Supp. at 1570-71).

280 See id. at 252 n.9; cf. Davis, 106 S. Ct. at 2834 (Powell, J., concurring and dissenting) (citing newspaper articles as evidence of invidious intent). Judge Gibbons made a point of questioning the trial court's decision that prevented the plaintiffs from deposing the defendant-legislators. He did not, however, reverse that decision because he decided such evidence would have been merely cumulative.

${ }^{281}$ Id. at 261-62 (Becker, J., dissenting). 
hearsay exception to the Federal Rules of Evidence because the people who attended the hearing did testify, and no "circumstantial guarantees of [the article's] trustworthiness" existed. ${ }^{262}$ Third, community perception of the statute was "simply too amorphous and unreliable to provide the ground for constitutional decisions."263 Fourth, the testimony of the education experts addressed the efficacy of the statute as an educational device, not impermissible motive. ${ }^{264}$ Fifth, prior attempts by the New Jersey legislature to pass prayer statutes were irrelevant. ${ }^{26 s}$ Therefore, Judge Becker argued, the court of appeals should have reversed.

Judge Gibbons's approach demonstrates the difficult nature of objective, not to mention subjective, contextual analysis of intent: its ambiguity invites judicial usurpation or characterization of the legislative function. Reliance on the totality of the circumstances to prove intent in the absence of the testimony of legislators, like Justice Powell's strong presumption of intent from the shape of districts in Davis, ${ }^{28 B}$ brings to mind Justice Stewart's test for obscenity: "I know it when I see it."267 Judge Becker's approach, at the other extreme, is excessively rigid. By isolating each factor, he is able to minimize its import; rather than considering the evidence in the aggregate, he considers the factors individually and easily dismisses them one after another.

Nonetheless, May actually presents an easier case to prove than does a political gerrymandering claim. The stakes involved in redistricting are extremely high. ${ }^{268}$ At the same time, the incentive to testify is

262 Id. at 262 (Becker, J., dissenting).

${ }^{263}$ Id. at 264 (Becker, J., dissenting).

${ }^{264}$ Id. at 264-65 (Becker, J., dissenting).

${ }^{265}$ Id. at 265 (Becker, J., dissenting).

${ }^{268}$ See Davis, $106 \mathrm{~S}$. Ct. at 2831-32 \& n.12 (Powell, J., concurring and dissenting); see also Daggett v. Kimmelman, 535 F. Supp. 978, 984 (D.N.J.) (three-judge panel) (Gibbons, J., dissenting) (commenting on the peculiar shapes of various districts), affd sub nom. Karcher v. Daggett, 462 U.S. 725 (1983).

267 Jacobellis v. Ohio, 378 U.S. 184, 197 (1964) (Stewart, J., concurring); cf. Congressional Districting: Hearings on H.R. 8953, and Related Proposals Before Subcomm. No. 5 of the House Comm. on the Judiciary, 92d Cong., 1st Sess. 98 (1971) (statement by Rep. Mikva) (Gerrymandering "is somewhat like pornography. You know it when you see it, but it's awfully hard to define.").

${ }^{268}$ See Davis, 106 S. Ct. at 2818 (O'Connor, J., concurring in the judgment) ("Apportionment is so important to legislators and political parties that the burden of proof the plurality places on political gerrymandering plaintiffs is unlikely to deter the routine lodging of such complaints."). Professor Cain, a consultant in the most recent California reapportionment, aptly observes that legislators approach redistricting motivated by risk aversion, not "with the joyous expectation of securing their careers for a decade." B. CAIN, supra note 84, at 116-17. Cain likens this to Downs's economic theory of democracy turned on its head. Instead of voters choosing their representatives, in redistricting representatives choose their voters. Id. at 117 (citing $\mathrm{A}$. DowNS, AN ECONOMIC TheoRy of Democracy 38-40 (1957)); of. Cain \& Campagna, supra 
low because political gerrymandering is not the type of issue for which legislators "welcome public exposure [or] believe that their own verbal and argumentative skills will protect their personal and institutional interests." 260

In Holmes v. Farmer, ${ }^{270}$ a 1984 redistricting case, legislators successfully asserted their evidentiary privilege. The plaintiffs in Holmes attempted to use testimony regarding the subjective motivations of key legislators and their aides to prove that the defendants had gerrymandered state legislative districts. ${ }^{271}$ The Rhode Island Supreme Court, however, sustained the invocation of the speech or debate testimonial privilege by legislators and their aides in litigation attacking the constitutionality of the reapportionment of the state house of representatives. ${ }^{272}$ The court, composed of former state legislators of both parties, ${ }^{273}$ also held that the trial court had erred in admitting the testimony of a state senator who purportedly waived her privilege from testifying, on the grounds that the privilege from inquiry into legislative acts accrued to the institution, not to the individual member. ${ }^{274}$ Since the plaintiffs were unable to prove intent, the plaintiffs failed to show that the defendants had redistricted solely for political considerations in violation of a state constitutional requirement. ${ }^{275}$ Consequently, the plaintiffs' suit failed. Although other courts may construe the privilege as nonevidentiary or, alternatively, construe it less broadly than did the Rhode Island court, legislators in these other jurisdictions are bound to cite Holmes in light of Davis.

note 17, at 267 (noting that while it is in the interest of an individual legislator of either party to engage in bipartisan trading to maintain the status quo, trading may further the interests of party leaders in improving party control of the legislature); Hardy, Considering the Gerrymander, 4 PEPPERDINE L. Rev. 243, 268-69 (1977) (noting that even where legislators profess an interest in gerrymandering for partisan purposes, self-interests are usually paramount); The 98.4\% House, Wall St. J., July 22 , 1987, at 20, col. 1 (editorial) (accusing Republican officeholders of striking a "Faustian" bargain with Democrats to guarantee the status quo).

${ }^{289}$ Raveson, supra note 191, at 924 n.304.

270475 A.2d 976 (R.I. 1984).

271 Id. at $984-85$.

${ }^{272}$ See id. at 980-85; cf. Hispanic Coalition on Reapportionment v. Legislative Reapportionment Comm'n, 536 F. Supp. 578, 583 n.4 (E.D. Pa.) (declining to consider issue of legislative immunity because complaint was dismissed on other grounds), aff $d$, 459 U.S. 801 (1982).

${ }^{279}$ See State of Rhode Island and Providence Plantations, Rhode IsLAND ManUal 293-96 (1983).

${ }^{274}$ See Holmes, 475 A.2d at 984 . The trial court later sustained objections to her testimony on relevancy grounds. Id. at 980 .

275 See id. at 984. 


\section{Finding a Way OUt of the Thicket:}

\section{A Return to Objective Analysis of Legislative Purpose}

Judicial reliance on a subjective analysis of the motives of legislators in redistricting litigation blocks the path out of the gerrymandering thicket by introducing two new traps. On one side is judicial review of a legislative enactment. ${ }^{278}$ On the other side is state legislative freedom from judicial interference. ${ }^{277}$

Professor Raveson argues that the way to avoid the traps and ascertain subjective motivation is to qualify the speech or debate evidentiary privilege. ${ }^{278}$ Professor Raveson proposes to balance the need for the evidence, its relevance, its probative value, and the importance of the proof "against the degree of harm that the government will suffer from the intrusion into the decisionmakers' independence . . .."278 What is important is identifying the marginal decisionmaker, determining the "but for" cause of a legislature's action. ${ }^{280}$ Implicit in Raveson's proposal, however, is a notion that the political process itself is valueneutral. ${ }^{281}$ The Court needs only a better way of ascertaining what considerations went into the process.

As Professor Baker has plainly put it, "[s]ubjective intent implies there is someone who has the intent." ${ }^{\text {"282 }}$ But even Professor Raveson, despite his sweeping claim that "objectively defined institutional intent . . . is a fiction," ${ }^{, 283}$ admits:

First, at times it may be impossible to prove any individual decisionmaker's motives. Second, when the decisionmaking body is large and the vote is not close, it may be impractical or impossible to establish, without other evidence, the motives of a sufficient number of individuals to prove that those motives affected the outcome of the deliberative process. Last, most of the types of evidence available to establish illicit motivation apply to the institution as a body and not to

${ }^{276}$ See Marbury v. Madison, 5 U.S. (1 Cranch) 137, 176-80 (1803) (establishing the doctrine of judicial review).

277 See Tenney v. Brandhove, 341 U.S. 367, 372-79 (1951) (affirming the doctrine of legislative immunity).

${ }^{278}$ See Raveson, supra note 191, at 943-44.

278 Id.

280 See id. at $955-57$.

${ }^{281}$ See, e.g., id. at 888 ("The Court allows the judiciary to nullify such legislative and administrative acts only when these processes have been tainted by impermissible considerations.").

282 Baker, supra note 174 , at 984 .

${ }^{283}$ Raveson, supra note 191, at 962. 
specific individuals. ${ }^{284}$

Professor Raveson thus posits that in ascertaining legislative intent a court should rely on an objective, contextual approach to legislative motivation.

The collapse of a subjective approach to legislative motivation is not surprising because, as Professor Baker points out, "[t]he social or contextual meaning of a law or act necessarily depends on the specific society that people create-on people's practices, on the politics of everyday life." ${ }^{288}$ In contrast to Professor Raveson's model, the equalityof-respect model of equal protection does not turn on the motives of the marginal decisionmaker. Instead, the equality-of-respect model focuses on the context in which a law exists. According to the subjective approach, legislative purpose is static. The marginal legislator's decision to vote a certain way cannot change over time. By definition, it is a question of history. Under an objective approach, on the other hand, legislative purpose can change, for example, "if the legislators' constitutional duty includes repealing laws that become invidious." 286 The Court removed any doubt as to that evolving duty in the redistricting context when, in Baker $v$. Carr, ${ }^{287}$ it held that the plaintiffs had a justiciable claim in seeking to compel the Tennessee legislature to redress a sixty-year-old redistricting scheme.

Justice Stevens recognized the trap of analyzing subjective motivation $^{288}$ in redistricting litigation in his prescient dissent in Cousins $v$. City Council ("Cousins I"). ${ }^{289}$ In that case, a Seventh Gircuit panel heard a challenge to the redistricting of the Chicago City Council. Relying on the compelled testimony of legislative aides ${ }^{280}$ and suggesting

284 Id. at 965; see also Goodman, De Facto School Segregation: A Constitutional and Empirical Analysis, 60 CAL. L. REv. 275, 284-85 (1972) (identifying the same problems).

${ }^{283}$ Baker, supra note 174, at 975.

286 Id. at 981.

287369 U.S. 186 (1964); see also Rogers v. Lodge, 458 U.S. 613, 622 (1982) (overturning an at-large redistricting plan that was adopted for racially neutral reasons but maintained for racially discriminatory ones); Baker, supra note 44, at 270 (referring to status quo gerrymandering in which a once legitimate redistricting scheme becomes distorted by population shifts over time); Baker, supra note 34, at 2 (same); Hardy, supra note 268, at 249-52 (identifying the same feature as the "silent gerrymander").

${ }^{288}$ For a concise discussion of Justice Stevens's approach to equal protection issues in general, see Note, Justice Stevens' Equal Protection Jurisprudence, 100 Harv. L. Rev. 1146 (1987).

289 466 F.2d 830, 856-57 (7th Cir.) (Stevens, J., dissenting), cert. denied, 409 U.S. 893 (1972) [hereinafter Cousins I].

200 See id. at 835-36 (Fairchild, J.). 
that the deposition of an alderman could be admissible, ${ }^{291}$ the court reversed a district court decision dismissing the challenge. ${ }^{292}$ Judge Stevens ${ }^{293}$ dissented. First, he relied on Justice White's dissent in Palmer v. Thompson ${ }^{284}$ to argue that subjective analysis of intent was unnecessary:

[C]ustomary indicia of legislative intent provide an adequate basis for ascertaining the purpose that a law is intended to achieve. The formal proceedings of the legislature and its committees, the effect of the measure as evidenced by its text, the historical setting in which it was enacted, and the public acts and deeds of its sponsors and opponents, provide appropriate evidence of legislative purpose. ${ }^{285}$

Second, Judge Stevens argued that a subjective inquiry was wrong. "[I]t demeans the legislative process to inquire into private conversations between aldermen . . ."296 To reiterate his objection to the use of the testimony of the aldermen's aides, Judge Stevens pointedly cited the brief of the United States Senate as amicus curiae in United States v. Gravel, ${ }^{287}$ which the Court had decided earlier that year. Two years later when Cousins re-appealed to the Seventh Circuit after remand ("Cousins II"), Judge Stevens changed his dissent to a concurrence. ${ }^{288}$ Whereas Judge Fairchild, writing for the court, had used a subjective approach in the first case, he focused on the objective claim in Cousins II. ${ }^{299}$

291 See id. at 845-46.

292 See id. at 846.

293 Justice Stevens served on the Seventh Circuit from 1970, see 429 F.2d xv (1970), until his 1975 appointment to the Court, see 423 U.S. xi-xiv (1975).

294403 U.S. 217, 240-71 (1971) (White, J., dissenting).

295 Cousins I, 466 F.2d at 856 (Stevens, J., dissenting); see also Karcher v. Daggett, 462 U.S. 725, 751, 759-60 (1983) (Stevens, J., concurring) (suggesting the consideration of "objective indicia of irregularity" or deviations from a "procedural standard"); Cousins v. City Council, 503 F.2d 912, 925 (7th Cir. 1974) (Stevens, J., concurring) (noting that in some cases the facts "spoke-indeed, shouted-for themselves.") [hereinafter Cousins II], cert. denied, 420 U.S. 992 (1975); cf. Hunter v. Underwood, 471 U.S. 222, 228-29 (1985) (resolving issue of intent without the use of "eyewitnesses" by relying on the uncontested testimony and opinions of historians); Baker, supra note 174, at 976-84 (discussing the Court's use of the contextual or objective purpose of a law as the "key constitutional concern").

${ }_{298}$ Cousins I, 466 F.2d at 856-57 (Stevens, J., dissenting) (footnote omitted).

297 See id. at 857 n.34 (quoting Brief for the Senate of United States Amicus Curiae at 12-13, United States v. Gravel, 408 U.S. 606 (1972)).

${ }^{298}$ See Cousins II, 503 F.2d at 925 (Stevens, J., concurring).

289503 F.2d 912 (7th Cir. 1974), cert. denied, 420 U.S. 992 (1975). Compare Cousins I, 466 F.2d at 834-37 (relying on the testimony of legislative aides) with Cousins II, 503 F.2d at 920 (noting that the testimony of legislative aides had some probative force, but refusing to reverse the district court's findings contrary to that 
Since the Cousins litigation, however, Justice Stevens appears to have drifted toward a more subjective approach to legislative intent. Although he insisted on an objective approach in City of Mobile $v$. Bolden, ${ }^{300}$ in Karcher $v$. Daggett ${ }^{301}$ Justice Stevens relied in part on a letter that the Speaker of the New Jersey Assembly had sent to a third party as proof of an invidious intent to gerrymander politically. ${ }^{\mathbf{3 0 2}}$ Thus, not surprisingly, Justice Powell's opinion in Davis, heavily influenced by Justice Stevens's opinion in Karcher, referred in detail to the depositions of those legislators who devised the plan. ${ }^{303}$ Justice White went even further, quoting the deposition of the Speaker of the Indiana House of Representatives verbatim. ${ }^{304}$

In light of these opinions in Davis ข. Bandemer, ${ }^{305}$ where can and should the Court go to escape the thicket? First, the Court must treat the Davis references to the subjective motivations of legislators as dicta and nothing more. Reliance on testimony regarding subjective motivation, as Justice Stevens himself cogently pointed out in Cousins $I$, is both unnecessary and wrong. ${ }^{306}$ It is unnecessary because other evidence of legislative purpose exists. It is wrong because it unjustifiably impinges on the speech or debate privilege, thus implicating separation of powers. Moreover, as Professor Baker has indicated, it is irrelevant. ${ }^{307}$ Redistricting exists in a social context. "[T]he role of law as

testimony).

soo 446 U.S. 55, 90 (1980) (Stevens, J., concurring); see also Blacksher \& Menefee, supra note 74, at 27-28 (discussing Justice Stevens's view in Mobile that a subjective approach would promote endless litigation); Moeller, supra note 70, at 222-23 (discussing Justice Stevens's concurrence).

${ }^{301} 462$ U.S. 725 (1983) (Stevens, J., concurring).

${ }^{302}$ See Karcher, 462 U.S. at 763-64 (Stevens, J., concurring). In Wallace v. Jaffree, a first amendment case, Justice Stevens focused heavily on the testimony of the sponsor of legislation, who sought to return voluntary prayer to the public schools, in ascertaining legislative purpose. See 472 U.S. 38, 56-61 (1985) (focusing on the motives of Alabama State Senator Donald Holmes).

To be fair to Justice Stevens, the private conversations in Cousins $I, 466$ F.2d at 856-57, and the letter in Karcher, 462 U.S. at 763-64, are arguably distinguishable in that the letter was widely circulated, whereas the private conversations were not. $C f$. Cousins I, 466 F.2d at 856 (Stevens, J., dissenting) (citing as a customary indicia of legislative intent "the public acts and deeds of ... sponsors and opponents"). Justice Stevens's distinction should not be dispositive, however, because both the private conversations and the letter reflect the motives of but a single individual.

${ }^{303}$ See id. at 2834 (Powell, J., concurring and dissenting) (referring to the testimony of the conference committee chairman).

sot See id. at 2802 n.5 (referring to the testimony of Speaker Dailey of the Indiana House of Representatives).

sos 106 S. Ct. 2797 (1986).

${ }^{308}$ See supra notes $293-97$ and accompanying text.

so7 See supra notes 284-86 and accompanying text (discussing the importance of the context in which a law exists rather than the subjective motivation of legislators in enacting the law). 
partially constituting the framework of social interaction . . . makes the contextual meaning, not the individual psychology of the enactors, most relevant." ${ }^{308}$ Professor Cain makes a persuasive argument that the motives of individual, risk-averse legislators confronted with redistricting can vary greatly from the purposes of political parties. ${ }^{309}$ Consequently, the Court must resist the temptation ${ }^{310}$ of holding that the testimony of legislators merely recreates what happened in the legislative process and thus is historically objective. ${ }^{311}$ Such reasoning would be a triumph of form over substance because what might begin as a mere recounting of history would quickly degenerate into a probe of subjective motives. ${ }^{312}$

Second, the Court must focus more on the objective standards of political gerrymandering, such as the of compactness concept advocated by Justice Powell. ${ }^{313}$ This Comment, however, specifically rejects some of the propositions advanced elsewhere. One proposal is to compare statistically the effect of the challenged plan against random, "computergenerated apportionment schemes having a population deviation no greater than that of the challenged plan."314 The difficulties with such a proposal are the same as with any other use of statistics in a social context: it is practically impossible to define a "random sample" or an effective measure of optimality. ${ }^{316}$ The suggestion that this measure can

308 Baker, supra note 174, at 975.

308 See B. CaIN, supra note 84, at 154-55; see also Lowenstein \& Steinberg, supra note 104, at 8 (noting that on certain issues, legislators' self-interests will cause them to desert the policies of their own parties).

310 See supra note 225 and accompanying text.

311 See, e.g, Sincock v. Gately, 262 F. Supp. 739,745 n.7 (D. Del. 1967) (allowing one legislator in a redistricting suit to testify as to the statements of another legislator even in the absence of a stenographic record and despite a hearsay objection); Comment, Statutory Interpretation in California: Individual Testimony as an Extrinsic Aid, 15 U.S.F. L. REv. 241, 247-52 (1980-81) (describing the California practice of allowing legislators to testify in lieu of recorded legislative history as to legislative history, but not subjective motivation).

312 See, e.g., In re Marriage of Bouquet, 16 Cal. 3d 583, 590-91, 546 P.2d 1371, 1374-75, 128 Cal. Rptr. 427, 430-31 (1976) (admitting a letter, written by the author of a statute to a member of the senate, that was incorporated into a senate resolution); In re Orans, 45 Misc. 2d 616, 643-44, 257 N.Y.S.2d 839, 865 (N.Y. Sup. Ct.) (using a letter written by one of several gerrymandering legislators as a basis for holding that a hearing on the activities of all the legislators was warranted), affd, 15 N.Y.2d 339, 206 N.E.2d 854, 258 N.Y.S.2d 825, appeal dismissed, 382 U.S. 10 (1965).

${ }^{313}$ Davis, $106 \mathrm{~S}$. Ct. at 2831-34 (Powell, J., concurring and dissenting) (focusing on the shape of the district).

314 Comment, supra note 18, at 135 (citing Engstrom, The Supreme Court and Equipopulous Gerrymandering: A Remaining Obstacle in the Quest for Fair and Effective Representation, 1976 ARIz. ST. L.J. 277, 316-18).

31s See, e.g., Engstrom, supra note 314, at 316-17 (suggesting an algorithm that would rely on a "random" beginning point and that would "randomly" combine precincts, yet failing to give any further content to this algorithm); Weaver \& Hess, $A$ 
be the basis of an allegation of gerrymandering ${ }^{316}$ must be rejected because it "does nothing to distinguish between proper and improper purposes." "317 A more feasible approach, incorporating existing communities of interests and recognizing the risk-aversion of legislators, is to redistrict on the basis of incremental change rather than through a tabula rasa method. ${ }^{318}$ Also known as "least change redistricting," the incremental change approach comports with the "virtues in having some continuity in office for the sake of experience, stability, and relations with constituents."

A second proposal also meriting swift rejection is to "require a specific degree of compactness." "320 "By dividing the area of the district

Procedure for Nonpartisan Districting: Development of Computer Techniques, 73 YaLE L.J. 288, 301-04 (1963) (advocating the use of computers to create "neutral plans," but admitting that certain decisions, such as the location of the centers of districts, are subject to human discretion); see also Lowenstein \& Steinberg, supra note 104, at 64 (arguing that "random" plans are meaningless if the overall distribution favors Republicans). But see Shapiro, supra note 69, at 246 (rejecting the argument of Lowenstein and Steinberg by noting that random districting is only unfair if the existing system is optimally fair, which it is not); Grofman, supra note 93, at 92 n.67 (noting the failure of Lowenstein and Steinberg to provide any empirical data to support their central contention).

${ }_{316}$ See Engstrom, supra note 313, at 318.

317 Lowenstein \& Steinberg, supra note 104, at 62.

s18 See Baker v. Carr, 369 U.S. 186, 260 (1962) (Glark, J., concurring) ("One plan might be to start with the existing assembly districts, consolidate some of them, and award the seats thus released to those counties suffering the most egregious discrimination."); B. CAIN, supra note 84 , at 50-51 (discussing an incrementalist method and its advantages over a tabula rasa system-it minimizes disruption to the political process and is fair to the political subdivisions involved). But see Auerbach, supra note 96, at 40 (suggesting that tabula rasa redistricting may promote legislative diversity); Weaver \& Hess, supra note 315 , at 289 n.6 (suggesting that tabula rasa redistricting will guarantee a prompt end to litigation); Comment, supra note 1, at 1039 (advocating tabula rasa redistricting by special masters). As the term suggests, tabula rasa redistricting begins with no preconceived notion of the districting. On the other hand, incremental change redistricting takes the status quo and then adjusts to reflect demographic change.

${ }_{310}$ Dixon, supra note 84, at 17; see also Lowenstein \& Steinberg, supra note 104 , at 45 (noting the reality of the seniority system in Congress); Comment, supra note 1, at 1039 (citing as the "obvious advantage" to this approach a court's ability to avoid having to weigh competing claims to representation).

${ }^{320}$ Comment, supra note 18 , at $135-36$ (suggesting a standard derived by state legislatures or courts); see also Comment, supra note 123, at 399 (suggesting a congressionally derived standard).

Congress first required contiguity and election from districts in 1842. See Act of June 25,1842 , ch. $47, \S 2,5$ Stat. 491, 491. Congress added requirements of population equality in 1872, see Act of Feb. 2, 1872, ch. 11, $\S 2,17$ Stat. 28, 28, and compactness in 1901, see Act of Jan. 16,1901, ch. 93, 33,31 Stat. 733, 734. Congress did not renew these standards in 1929. See Act of June 18, 1929, ch. 28, § 22, 46 Stat. 21, 26-27; see also Wood v. Broom, 287 U.S. 1, 6-7 (1932) (discussing the history of the 1929 Act). See generally Weschler, The Political Safeguards of Federalism: The Role of the States in the Composition and Selection of the National Government, 54 Colum. L. REv. 543, 550 (1954) (detailing congressional efforts to regulate state redis- 
by the area of the smallest possible circumscribing circle, the degree of compactness can be expressed as a percentage, with a circle representing the 'ideal of compactness,' just as the average district population is used as the ideal of population equality." ${ }^{321}$ This proposal is illogical: as one district becomes more circular, thus approaching the "ideal," every contiguous district becomes less circular, thus retreating from the "ideal." 322 Furthermore, as other commentators have pointed out, such a proposal gives an advantage to the party that can create the "prettiest" gerrymander because voters are not spatially distributed. ${ }^{323}$ The suggestion that the courts "gradually develop a degree of compactness below which a challenger's initial burden of showing vote dilution would be satisfied"324 minimizes variations that are the result of population and geography within and among states. ${ }^{325}$

But the Court need not lapse into saying "it knows a gerrymander when it sees it." Instead, what the Court must say is that "it will presume a gerrymander when it sees it." An obvious lack of compactness, for example, may give rise to that presumption, but the state will then have the opportunity to rebut it without having to submit to any inquiry into the subjective motivations of individual legislators. In Karcher, Justice Brennan used such a burden-shifting standard, which

tricting of congressional districts). In 1967, however, Congress restored the requirement of election from districts. See Act of Dec. 14, 1967, Pub. L. No. 90-196, 81 Stat. 581, 581 (codified at 2 U.S.C. $\$ 2 c(1982)$ ). Congress has since considered, but not adopted, other "anti-gerrymandering" provisions. See, e.g., S. 596, 96th Cong., 1st Sess. § 2, 125 CoNG. REc. 4419-20 (1979) (requiring population equality, respect for the boundaries of local political subdivisions, contiguity, and compactness, and eschewing the use of political data and attempts at vote dilution).

${ }^{321}$ Comment, supra note 18, at 136 (citing Reock, Measuring Compactness as a Requirement of Legislative Apportionment, 5 MidwEST J. PoL. ScI. 70, 71 (1961)).

322 See Alfange, supra note 5, at 213; Backstrom, supra note 101, at 50; Dixon, supra note 1 , at 250.

${ }^{323}$ See, e.g., B. CAIN, supra note 84, at 51 (discussing the "fundamental tension" between aesthetic criteria and the good government goals of fair representation of minority groups and minority parties); P. Musgrove, supra note 6 , at 53 (cautioning that the criterion of compactness introduces a bias if the perfect gerrymander differs as to parties); cf. Opinion to the Governor, 101 R.I. 203, 207-08, 221 A.2d 799, 802 (1966) ("compactness" is a principle based on an intent to provide effective representation that varies with the context, not a definition).

More than twenty years ago, Professor Vickrey demonstrated by example why a compactness measure based on a geometric criterion such as that advocated by Reock can yield a meaningless result. See Vickrey, On the Prevention of Gerrymandering, 76 Pol. ScI. Q. 105, 105 (1961).

s24 Comment, supra note 18 , at 136.

328 See Reock, supra note 321, at 73-74 (conceding that a statutory degree of compactness is not possible in light of interstate geographical variations such as "panhandles" and "heavily indented coastlines" but failing to recognize, as Professors Cain and Musgrove do, see supra note 323, that a compactness standard can also have an intrastate bias if the perfect gerrymander differs as to parties). 
attempts to ascertain the optimal redistricting plan:

First, the court must consider whether the population differences among districts could have been reduced or eliminated altogether by a good-faith effort to draw districts of equal population. Parties challenging apportionment legislation must bear the burden of proof on this issue, and if they fail to show that the differences could have been avoided the apportionment scheme must be upheld. If, however, the plaintiffs can establish that the population differences were not the result of a good-faith effort to achieve equality, the State must bear the burden of proving that each significant variance between districts was necessary to achieve some legitimate goal. $^{326}$

In ascertaining good faith, the Court should also focus objectively on the process by which the plan was adopted. Critical to that inquiry is the existence of the opportunity for individuals to participate independently and in groups. ${ }^{327}$ In Davis, for example, "[ $\left.t\right]$ he legislative process consisted of nothing more than the majority party's private application of computer technology to mapmaking." ${ }^{328}$ Such a lack of real participation must give rise to a strong presumption of political gerrymandering.

In summary, the Court must return to Judge Stevens's crisp, articulate reasoning in the Cousins litigation. If gerrymandering is a justiciable question, then the objective purpose of the plan, not the subjective motivations of those behind it, is what is relevant. This focus is a reasonable one for the Court to take, but in doing so the Court must make it clear that subjective motivations such as those mentioned in Davis are

${ }^{\text {s26 }}$ Karcher, 462 U.S. at 730-31 (Brennan, J., for himself and Marshall, Blackmun, Stevens, \& O'Connor, JJ.) (citations omitted); see also id. at 754-55 (Stevens, J., concurring) (recognizing the difficulty plaintiffs will have in meeting their burden of proof); cf. Opinion to the Governor, 101 R.I. at 211, 221 A.2d at 803-04 (refusing to holding redistricting plan unconstitutional on the basis of maps alone).

With regard to variations from compactness, the Colorado legislature, for example, has stated that such variations are the result of "the shape of county boundary lines, census enumeration lines, natural boundaries, population density, and the need to retain compactness of adjacent districts." Karcher, 462 U.S. at 757 n.20 (Stevens, J., concurring) (citing Colo. Rev. STAT. §§ 2-2-105, 2-2-203 (1980)).

s22 See Davis, 106 S. Ct. at 2832-33 (Powell, J., concurring and dissenting, joined by Stevens, $J$.) (noting the exclusion of Democrats from the redistricting process); $i d$. at 2817 (O'Connor, J., concurring in the judgment with Burger, C.J., \& Rehnquist, J.) (redistricting plays "no small role in fostering active participation in the political process at every level"); see also Baker, supra note 174, at 960-63 (describing the political participation principle of the equality of respect model).

${ }^{328}$ Davis, 106 S. Ct. at 2833 (Powell, J., concurring and dissenting). 
immaterial.

\section{ConClusion}

The Court's movement toward proportional representation dates back forty years to Justice Black's dissent in Colegrove v. Green. ${ }^{\mathbf{3 2}}$ Since then proportional representation has manifested itself in a variety of forms, including racial, numerical, and political gerrymandering. A requirement of proportional representation, howèver, is inconsistent with the "deliberative democracy" model of the Constitution. In Davis v. Bandemer, ${ }^{330}$ the Court attempted to halt the slide towards proportional representation. The equal protection standards the Court used, however, are problematic. Justice White's opinion offers little guidance. Justice Powell's opinion is more helpful, noting objective criteria such as compactness and the extent of political participation in the redistricting. But both opinions refer to the subjective motivations of individual legislators. As the equality of respect model of equal protection suggests, these references are wrong. Consequently, in future cases, the Court should abandon that language and focus on strengthening the objective standards offered by Justice Powell. Perhaps then, the courts and the state legislatures will find a path out of the gerrymandering thicket. 
$$
\text { . }
$$

. 